DEPARTMENT OF THE IMTERIOR

U.S. GEOLOGICAL SURVEY

Publications of the U.S. Geological Survey Geothermal Research Program, 1982-1986

Open-File Report $87-439$

This report is preliminary and has not been reviewed for conformity with U.S. Geological Survey editorial standards. 


\section{PUBLICATIONS OF THE GEOTHERMAL RESEARCH PROGRAM \\ U.S. Geological Survey \\ 1982-1986}

(A) Abstract

(O) Open-File reports

(P) Published reports, maps, etc.

(A) Achauer, U., Greene, L., Evans, J. R., and Iyer, H. M., 1984, Evidence for a low-velocity body under Inyo/Kono Craters from the study of teleseismic P-wave traveltime residuals (abs.): Eos, Transactions American Geophysical Union, v. 65, p. 1116.

(P) Achauer, U., Greene, L., Evans, J. R., and Iyer, H. M., 1986, Nature of the magma chamber underlying the Mono Craters area, eastern California, as determined from teleseismic travel time residuals: Journal of Geophysical Research, v. 91, p. 13,873-13,891.

(A) Adam, D. P., Sarna-Wojcicki, A. M., Bradbury, J. P., Dean, W. E., Forester, R. M., and Rieck, H. J., 1986, Tule Lake, California: A 3.0-m.y. core record from the Modoc Plateau (abs.): American Quaternary Association Program and Abstracts, no. 9, p. 112.

(P) Aducci, A. J., Klick, D. W., and Wallace, R. H., Jr., 1986, Management of the Salton Sea scientific drilling program: Geothermal Resources Council Transactions, v. 10, p. 445-448.

(A) Anderson, L. A., 1985, Self-potential investigations in the Puhimau thermal area, Kilauea volcano, Hawaii (abs.): Geophysics, v. 50, P.274.

(0) Anderson, W. L., 1982, Adaptive nonlinear least-squares solution for constrained or unconstrained minimization problems (Subprogram NLSOL): U.S. Geological Survey Open-File report 82-68, 65p.

(O) Anderson, W. L., 1982, Calculation of transient soundings for a coincident loop system (Program TCOLOOP): U.S. Geological Survey Open-File report $82-378,77 p$.

(0) Anderson, W. L., 1982, Fast evaluation of squared-Hankel transforms of order-1 by linear digital filtering (Subprogram SQJ1): U.S. Geological Survey Open-File report 82-224, 13p.

(P) Anderson, W. L., 1982, Fast Hankel transforms using related and lagged convolutions: Association for Computer Mach. Trans. on Mathematical Software, v. 8, no. 4, p. 344-368.

(0) Anderson, W. L., 1982, Nonlinear least-squares inversion of transient soundings for a central induction loop system (Program NLSTCI): U.S. Geological Survey Open-File Report 82-1129, 85 p.

(0) Anderson, W. L., 1982, Nonlinear least-squares inversion of transient soundings for a coincident loop system (Program NLSTCO): U.S. Geological Survey Open-File Report 82-1064, 81 p.

(0) Anderson, W. L., 1983, Fourier cosine and sine transforms using lagged convolutions in double-precision (Subprograms DLAGFO/DLAGF1): U.S. Geological Survey Open-File Report 83-320, $38 \mathrm{p}$.

(0) Anderson, W. L., 1984, A general interface for producing forward solution programs (Subprogram FWDSOL): U.S. Geological Survey Open-File Report 84-348, $43 \mathrm{p}$.

(P) Anderson, W. L., 1984, Computation of Green's tensor integrals for three-dimensional electromagnetic problems using fast Hankel transforms: Geophysics, v. 49, p. 1754-1759.

(P) Anderson, W. L., 1984, Discussion on: Numerical integration of related Hankel transforms by quadrature and continued fraction expansion (A. D. Chave): Geophysics, v. 49, p. 1811-1812. 
(0) Anderson, W. L., 1984, Fast evaluation of $\mathrm{Hr}$ and $\mathrm{Hz}$ field soundings near a rectangular loop source on a layered earth (Program HRZRECT): U.S. Geological Survey Open-File Report 84-257, 80 p.

(0) Anderson, W. L., 1985, Computation of transient soundings for the time-derivative of $\mathrm{Hz}$ near a rectangular loop source on a layered earth (Program FWDTHZ): U.S. Geological Survey Open-File Report 85-270, $44 \mathrm{P}$.

(0) Anderson, W. L., Frischknecht, F. C., Bradley, J. A., Grette, R., and Gross, C., 1983, Inversion results of time-domain electromagnetic soundings near Medicine Lake, California (part 2): U.S. Geological Survey Open-File Report 84-910, 29 p.

(0) Anderson, W. L., Frischknecht, F. C., Raab, P. V., Bradley, J. A., and Turnross, J., 1983, Results and preliminary inversion of loop-loop frequency-domain electromagnetic soundings near Medicine Lake, California: U.S. Geological Survey Open-File Report 83-830, $126 \mathrm{p}$.

(0) Anderson, W. L., Frischknecht, F. C., Raab, P. V., Bradley, J. A., Turnross, J., and Buckley, T. W., 1983, Inversion results of time-domain electromagnetic soundings near Medicine Lake, California, geothermal area: U.S. Geological Survey Open-File Report 83-233, $31 \mathrm{p}$.

(0) Anderson, W. L., and Newman, G. A., 1985, An album of three-dimensional transient electromagnetic responses for the central-induction loop configuration: U.S. Geological Survey Open-File Report 85-745, 95 p.

(0) Anderson, W. L., and Smith, B. D., 1984, Nonlinear least-squares inversion of transient induced polarization data (Program NLSTIP): U.S. Geological Survey Open-File Report 84-514, $63 \mathrm{p}$.

(P) Bacon, C. R., 1982, Time-predictable bimodal volcanism in the Coso Range, California: Geology, v. 10, p. 65-69.

(P) Bacon, C. R., 1983, Eruptive history of Mount Mazama and Crater Lake caldera, Cascade Range, USA in Aramaki, S., and Kushiro, I., eds., Symposium on Arc volcanism: Journal of Volcanology and Geothermal Research, v. 18 , p. 57-115.

(A) Bacon, C. R., 1983, Possible relations between magmatism, rates of extension, and the state of stress in the crust (abs.): Geological Society of America Abstracts with Programs, v. 15, no. 5, p. 288.

(A) Bacon, C. R., 1983, The precursory and climactic eruptions of Mount Mazama and collapse of Crater Lake caldera, Oregon (abs.):

Geological Society of America Abstracts with Programs, v. 15, no. 5, P. 330 .

(0) Bacon, C. R., 1984, Implications of silicic vent patterns for the presence of large crustal magma chambers, in Hill D. P., Bailey, R. A., and Ryal1, A. S., eds., Active tectonic and magmatic processes beneath Long Valley caldera, eastern California: U.S. Geological Survey Open-File Report 84-939, p. 830-850.

(A) Bacon, C. R., 1984, Magmatic inclusions in silicic and intermediate volcanic rocks as windows into compositionally zoned igneous systems, in Dungan, M. A., Grove, T. L., and Hildreth, Wes, eds., Proceedings of the Conference on Open Magmatic Systems, Ranchos de Taos, New Mexico: Southern Methodist University, p. 6-8.

(P) Bacon, C. R., 1985, Implications of silicic vent patterns for the presence of large crustal magma chambers: Journal of Geophysical Research, v. 90, p. $11,243-11,252$.

(A) Bacon, C. R., 1985, Mount Mazama and Crater Lake caldera, in Guffanti, M. and Muffler, L. J. P, eds., 1985, Proceedings of the workshop on geothermal resources of the Cascade Range: U.S. Geological Survey Open-File Report 85-521, p. 37-39. 
(P) Bacon, C. R., 1986, Magmatic inclusions in silicic and intermediate volcanic rocks: Journal of Geophysical Research, v. 91, p. 6091-6112.

(A) Bacon, C. R., Bennett, B. S., and Ho, P. Y. W., 1984, Geologic panoramas of the walls of Crater Lake caldera, Oregon, plotted on a computer-contoured topographic base (abs.): Geological Society of America Abstracts with Programs, v. 16, no. 6, p. 434.

(A) Bacon, C. R., and Druitt, T. H., 1986, Petrologic evidence for recharge and convective mixing in the magma chamber of Mount Mazama before its catastrophic zoned eruption and the collapse of Crater Lake caldera, Oregon (abs.): International Mineralogical Association 14th general meeting Abstracts with Program, p. 48.

(P) Bacon, C. R., Giovannetti, D. M., Duffield, W. A., Dalrymple, G. B., and Drake, R. E., 1982, Age of the Coso Formation, Inyo County, California: U.S. Geological Survey Bulletin 1527, 18 p.

(P) Bacon, C. R., Kurasawa, H., Delevaux, M. H., Kistler, R. W., and Doe, B. R., 1984, Lead and strontium isotopic evidence for crustal interaction and compositional zonation in the source regions of Pleistocene basaltic and rhyoloitic magmas of the Coso volcanic field, California: Contributions to Mineralogy and Petrology, v. 85, p. 366-375.

(A) Bacon, C. R., and Lanphere, M. A., 1983, K-Ar chronology of eruptions at Mount Mazama before the formation of Crater Lake caldera (abs.): Eos, Transactions American Geophysical Union, v. 64, p. 879.

(P) Bacon, C. R., Metz, J., 1984, Magmatic inclusions in rhyolites, contaminated basalts, and compositional zonation beneath the coso volcanic field, California: Contributions to Mineralogy and Petrology, v. 85, p. 346-365.

(A) Bailey, R. A., 1983, Postcaldera evolution of the Long Valley magma chamber, eastern California (abs.): Eos, Transactions American Geophysical Union, v. 64, p. 889.

(O) Bailey, R. A., 1984, Chemical evolution and current state of the Long Valley magma chamber, in Hill D. P., Bailey, R. A., and Ryall, A. S., eds., Active tectonic and magmatic processes beneath Long Valley caldera, eastern California: U.S. Geological Survey Open-File Report 84-939, p. 24-40.

(P) Bailey, R. A., 1984, Introduction to the late Cenozoic volcanism and tectonics of the Long Valley-Mono Basin area, eastern California, in Lintz, Joseph, Jr., ed., Guidebook to western geological excursions: Geological Society of America Annual Meetings, Reno, Nevada, v. 2, p. 56-67.

(A) Bailey, R. A., 1984, Postcaldera evolution of the Long Valley magma chamber, California, in Dungan, M. A., Grove, T. L., and Hildreth, Wes, eds., Proceedings of the Conference on Open Magmatic Systems: Ranchos de Taos, New Mexico, Southern Methodist University, p. 9.

(A) Bailey, R. A., Macdonald, R. A., and Thomas, J. E., 1983, Mono-Inyo craters:products of an actively differentiating rhyolite magma chamber, eastern California (abs.): Eos, Transactions American Geophysical Union, v. 64, p. 336 .

(P) Baker, M. R., Braile, L. W., and Smith, R. B., 1982, Amplitude and phase normalization of seismograms from multiple seismograph recording systems for the Yellowstone-Snake River Plain seismic refraction experiment: Journal Geophysical Research, v. 87, p. 2611-2618.

(P) Bargar, K. E., and Beeson, M. H., 1984, Hydrothermal mineralogy of research drill hole $Y-3$, Yellowstone National Park, Wyoming: Geothermal Resources Council Transactions, v. 8, p. 111-117. 
(P) Bargar, K. E., and Beeson, M. H., 1985, Hydrothermal alteration in research drill hole $Y-3$, Lower Geyser Basin, Yellowstone National Park, Wyoming: U.S. Geological Survey Professional Paper 1054-C, $23 \mathrm{p}$.

(A) Bargar, K. E., Fournier, R. O., and Theodore, T. G., 1984, Particles resembling bacteria in fluid inclusions from Yellowstone National Park, Wyoming (abs.): Geological Society of America Abstracts with Programs, v. 16 , no. 6 , p. 436-437.

(P) Bargar, K. E., Fournier, R. O., and Theodore, T. G., 1985, Particles in fluid inclusions from Yellowstone National Park - bacteria?: Geology, v. 13, p. 483-486.

(P) Bargar, K. E., Fournier, R. O., and Theodore, T. G., 1986, Reply to comments on "Particles in fluid inclusions from Yellowstone National Park - bacteria?": Geology, v. 14, p. 90-91.

(0) Bargar, K. E., and Keith, T. E. C., 1984, Hydrothermal alteration mineralogy in Newberry 2 drill core, Newberry Volcano, Oregon: U.S. Geological Survey Open-File Report 84-92, 62 p.

(0) Bargar, K. E., and Keith, T. E. C., 1986, Hydrothermal mineralization in GEO N-1 drill hole, Newberry volcano, oregon: U.S. Geological Survey Open-File Report 86-0440, 12 p.

(P) Bargar, K. E., and Muffler, L. J. P., 1982, Hydrothermal alteration in research drill hole $Y-11$ from a vapor-dominated geothermal system at Mud Volcano, Yellowstone National Park, Wyoming: Wyoming Geological Association Thirty-Third Field Conference Guidebook, v. 33, p. 139-152.

(0) Beeson, M. H., and Bargar, K. E., 1984, Major and trace element analyses of drill cores from thermal areas in Yellowstone National Park, Wyoming: U.S. Geological Survey Open-File Report 84-373, 40 p.

(0) Benson, S. M., Janik, C. J., Long, D. C., Solbau, D., Lineau, P. J., and others, 1984, Data from pumping and injection tests and chemical sampling in the geothermal aquifer at Klamath Falls, Oregon: U.S. Geological Survey Open-File Report 84-146, $114 \mathrm{p}$.

(P) Benz, H. H., and Smith, R. B., 1984, Simultaneous inversion for lateral velocity variations in the Yellowstone region using earthquake and refraction data: Journal of Geophysical Research, v. 89, p. 1208-1220.

(0) Berge, P. A., 1985, Teleseismic P-wave traveltime residuals across the Casacade Range in southern Oregon: U.S. Geological Survey Open-File Report 85-622, $104 \mathrm{p}$.

(P) Berge, P. A., Dawson, P. B., and Evans, J. R., 1985, Active seismic imaging experiment: Eos, Transactions American Geophysical Union, v. 66, p. 603-604.

(0) Berge, P. A., Evans, J. R., Zucca, J. J., Kohler, W. M., Mooney, W. D., Dawson, P. B., and Smith, M. H., 1986, High-resolution seismic investigation of the Medicine Lake volcano, California: U.S. Geological Survey Open-File Report 86-362, 101 p.

(0) Berge, P. A., and Monfort, M. B., 1986, Teleseismic residual study of the Lassen Volcanic National Park region in California: U.S. Geological Survey Open-File Report 86-0252, $71 \mathrm{p}$.

(A) Berge, P. A., and Walter, S. R., 1984, Upper crustal structure of the Lassen Peak area, northern California, from seismicity and refraction data (abs.): Eos, Transactions American Geophysical Union, v. 65, p. 985 .

(0) Bisdorf, R. J., 1983, Schlumberger soundings near Newberry Caldera, Oregon: U.S. Geological Survey Open-File Report 83-825, 51 p.

(P) Bisdorf, R. J., 1985, Schlumberger sounding results over the Newberry volcano area, Oregon: Geothermal Resources Council Transactions, v. 9, part II, p. 389-394. 
(A) Blakely, R. J., 1982, Magnetic models of volcanic terrane: Accounting for the effects of topography (abs.): Eos, Transactions American Geophysical Union, v. 63, p. 909.

(P) Blakely, R. J., 1985, The effect of topography on aeromagnetic data in the wavenumber domain: Institute de Geophysique, Bulletin 7, p. 102-109.

(A) Blakely, R. J., 1985, The effect of topography on aeromagnetic data in the wavenumber domain (abs.): Eos, Transactions American Geophysical Union, v. 66, p. 869 .

(A) Blakely, R. J., 1986, Mapping the depth to the Curie-temperature isotherm with aeromagnetic data from Nevada (abs.): Eos, Transactions American Geophysical Union, v. 67, p. 920.

(P) Blakely, R. J., and Grauch, V. J. S., 1983, Magnetic models of crystalline terrane: accounting for the effect of topography: Geophysics, v. 48, p. 1551-1557.

(A) Blakely, R. J., Jachens, R. C., Simpson, R. W., and Couch, R. W., 1983, Tectonic setting of the southern Cascade Range as interpreted from its magnetic and gravity fields (abs.): Eos, Transactions American Geophysical Union, v. 64, p. 886.

(P) Blakely, R. J., Jachens, R. C., Simpson, R. W., and Couch, R. W., 1985, Tectonic setting of the southern Cascade Range as interpreted from its magnetic and gravity fields: Geological Society of America Bulletin, v. 96 , p. 43-48.

(P) Bliss, J. D., 1983, GEOTHERM data tape giving geochemistery of geothermal springs, wells in the United States: National Technical Information Service, Springfield, Virginia, PB-84107705.

(0) Bliss, J. D., 1983, Alaska--Basic data for thermal springs and wells as recorded in GEOTHERM: U.S. Geological Survey Open-File Report 83-426, $118 \mathrm{p}$.

(0) Bliss, J. D., 1983, Arizona--Basic data for thermal springs and wells as recorded in GEOTHERM: U.S. Geological Survey Open-File Report 83-427, $206 \mathrm{p}$.

(0) Bliss, J. D., 1983, California--Basic data for thermal springs and wells as recorded in GEOTHERM, Part A: U.S. Geological Survey Open-File Report 83-428A, $109 \mathrm{p}$.

(0) Bliss, J. D., 1983, California--Basic data for thermal springs and wells as recorded in GEOTHERY, Part B: U.S. Geological Survey Open-File Report 83-428B, $860 \mathrm{p}$.

(0) Bliss, J. D., 1983, Central and Eastern United States--Basic data for thermal springs and wells as recorded in GEOTHERM: U.S. Geological Survey Open-File Report 83-440, $87 \mathrm{p}$.

(0) Bliss, J. D., 1983, Colorado--Basic data for thermal springs and wells as recorded in GEOTHERM: U.S. Geological Survey Open-File Report 83-429, $176 \mathrm{p}$.

(0) Bliss, J. D., 1983, Hawaii--Basic data for thermal springs and wells as recorded in GEOTHERM: U.S. Geological Survey Open-File Report $83-430,24 \mathrm{p}$.

(0) Bliss, J. D., 1983, Idaho--Basic data for thermal springs and wells as recorded in GEOTHERM, Part A: U.S. Geological Survey Open-File Report 83-431A, $64 \mathrm{p}$.

(0) Bliss, J. D., 1983, Idaho--Basic data for thermal springs and wells as recorded in GEOTHERM, Part B: U.S. Geological Survey Open-File Report 83-431B, $509 \mathrm{p}$.

(0) Bliss, J. D., 1983, Montana--Basic data for thermal springs and wells as recorded in GEOTHERM: U.S. Geological Survey Open-File Report 83-432, $166 \mathrm{p}$.

(0) Bliss, J. D., 1983, Nevada--Basic data for thermal springs and wells as recorded in GEOTHERM, Part A: U.S. Geological Survey Open-File Report 83-433A, $102 \mathrm{p}$. 
(0) Bliss, J. D., 1983, Nevada--Basic data for thermal springs and wells as recorded in GEOTHERM, Part B: U.S. Geological Survey Open-File Report 83-433B, $712 \mathrm{p}$.

(0) Bliss, J. D., 1983, New Mexico--Basic data for thermal springs and wells as recorded in GEOTHERH: U.S. Geological Survey Open-File Report 83-434, $175 \mathrm{p}$.

(0) Bliss, J. D., 1983, Oregon--Basic data for thermal springs and wells as recorded in GEOTHERM: U.S. Geological Survey Open-File Report 83-435, $247 \mathrm{p}$.

(0) Bliss, J. D., 1983, Texas--Basic data for thermal springe and wells as recorded in GEOTHERM: U.S. Geological Survey Open-File Report 83-436, $437 \mathrm{p}$.

(0) Bliss, J. D., 1983, Utah--Basic data for thermal springs and wells as recorded in GEOTHERH: U.S. Geological Survey Open-File Report 83-437, $385 \mathrm{p}$.

(0) Bliss, J. D., 1983, Washington State--Basic data.for thermal springs and wells as recorded in GEOTHERM: U.S. Geological Survey Open-pile Report 83-438, $50 \mathrm{p}$.

(0) Bliss, J. D., 1983, Wyoming--Basic data for thermal springs and wells as recorded in GEOTHERM: U.S. Geological survey Open-File Report 83-439, $216 \mathrm{p}$.

(P) Bliss, J. D., 1986, Management of Earth-science databases and a small matter of data quality: in Hanley, J. T., and Merriam, D. F., eds., Microcompyter Applications in Geology, Computers and Geology, v. 5, p. 113-120.

(P) Bliss, J. D., 1986, Management of the life and death of an earth-science database: some examples from GEOTHERH: Computers and Geosciences, v. 12, P. 199-205.

(P) Bode11, J. M., and Chapman, D. S., 1982, Heat flow in the north-central Colorado Plateau: Journal of Geophysical Research, v. 87, p. 2869-2884.

(P) Braile, L. W., Smith, R. B., Ansorge, J., Baker, M. R., Sparlin, M. A., Prodehl, C., Schilly, M. M., Healy, J. H., Mueller, S., and Olsen, K. H., 1982. The Yellowstone-Snake River Plain seismic profiling experiment: crustal structure of the Eastern Snake River Plain: Journal of Geophysical Research, v. 87, p. 2597-2609.

(0) Broker, M. M., Christopherson, K., and Heller, R., 1982, E-field ratio telluric survey near Medicine Lake in the Medicine Lake Highlands caldera, Siskiyou County, California: U.S. Geological Survey Open-File Report 82-900, 11 p.

(P) Bufe, C. G., 1982, Geothermal energy (annual review): Geotimes, v. 27, no. 2, p. 37-39.

(P) Bufe, C. G., 1983, Geothermal energy (annual review): Geotimes, v. 28, no. 2, p. 22-24.

(0) Byerlee, J. D., and Horrow, C. A., 1983, Final report on the permeability of geopressured Gulf Coast shale cores: U.S. Geological Survey Open-File report 83-0180, $9 \mathrm{p}$.

(A) Catchings, R. D., Mooney, W. D., Puis, G. S., 1983, Seismic investigation of Medicine Lake Volcano: Structure and probable genesis (abs.): Bos, Transactions American Geophysical Union, v. 64, p. 899.

(A) Champion, D. E., and Christiansen, R. L., 1984, Occurences of self-reversing remanent magnetization in pyroclastic deposits of $\mathrm{Mt}$. Shasta, California (abs.): Eos, Transactions American Geophysical Union, v. 65, p. 861 .

(P) Chatterjee, S. M., Pitt, A. H., and Iyer, H. H., 1985, $\mathbf{V}_{\mathbf{p}} / \mathrm{V}_{\mathbf{s}}$ ratios in the Yellowstone National Park Region, Wyoming: Journal of Volcanology and Geothermal Research, v. 26, p. 213-230. 
(0) Christiansen, R. L., 1984, Postcaldera evolution and current activity of the Yellowstone caldera, in Hill D. P., Bailey, R. A., and Ryall, A. S., eds., Active tectonic and magmatic processes beneath Long Valley caldera, eastern California: U.S. Geological Survey Open-File Report 84-939, p. 743-783.

(A) Chritiansen, R. L., 1985, The Mount Shasta magmatic system, in Guffanti, M., and Muffler, L. J. P, eds., 1985, Proceedings of the workshop on geothermal resources of the Cascade Range: U.S. Geological Survey Open-File Report 85-521, p. 31-33.

(A) Clague, D. A., 1982, Petrology of tholeiitic basalt dredged from Hualalai Volcano, Hawaii (abs.): Eos, Transactions American Geophysical Union, v. 63 , p. 1138.

(A) Clague, D. A., 1982, The Hawailan-Emperor volcanic chain: Implications for the origin of mid-plate volcanoes (abs.): Seamount Symposium, November 17-19, 1982, Lamont-Doherty Geological Observatory, New York.

(0) Clague, D. A., and Bohrson, W. A., 1985, Preliminary geologic map of Keahole Pt. Quadrangle, Hawaii: U.S. Geological Survey Open-File Report 85-586, 1 plate, scale 1:24,000.

(0) Clague, D. A., and Bohrson, W. A., 1985, Preliminary geologic map of Makalawena Quadrangle, Hawai i: U.S. Geological Survey Open-File Report 85-595, 1 plate, scale 1:24,000.

(A) Clague, D. A., Moore, J. G., and Normark, W. R., 1982, Loihi Seamount, The youngest Hawailan volcano (abs.): Abstract volume, Generation of major basalt types, IAVCEI/IAGC Scientific Assembly, Reykjavik, Iceland, 1982, no. 42.

(A) Clynne, M. A., 1984, Stratigraphy and major element geochemistry of the Lassen volcanic center, California (abs.): Eos, Transactions American Geophysical Union, v. 65, p. 1135.

(A) Clynne, M. A., 1985, Quaternary volcanism in the southermost Cascade Range, California, in Guffanti, M., and Muffler, L. J. P, eds., 1985, Proceedings of the workshop on geothermal resources of the Cascade Range: U.S. Geological Survey Open-File Report 85-521, p. 24-30.

(P) Connard, G., Couch, R., and Gemperle, K., 1983, Analysis of aeromagnetic measurements from the Cascade Range in central Oregon: Geophysics, v. 48, p. $376-390$.

(P) Corwin, R. F., and Fitterman, D. V., 1983, Self-potential survey results-Makushin volcano geothermal area, Unalaska Island, Alaska:

Geothermal Resource Council Transactions, v. 7, p. 89-94.

(P) Costain, J. K., Speer, J. A., Glover III, L., Perry, L., Dashevsky, S., and McKinney, M., 1986, Heat flow in the Piedmont and Atlantic Coastal Plain of the southeastern United States: Journal of Geophysical Research, v. 91, p. 2123-2135.

(0) Couch, R. W., 1982, Maps showing total-field aeromagnetic anomalies and topography of the Cascade Mountain Range, northern California: U.S. Geological Survey open-File report 82-0198, 2 sheets, scale 1:250,000.

(0) Couch, R. W., and Gemperle, M., 1982, Aeromagnetic measurements in the Cascade Range and Modoc Plateau of northern Californaia - June 1 , 1980 to November 30, 1980: U.S. Geological Survey Open-File report 82-0932, $26 \mathrm{p}$.

(0) Couch, R. W., and Gemperle, M., 1982, Aeromagnetic measurements in the Cascade Range and Modoc Plateau of northern Californaia - December 1 , 1980 to May 31, 1981: U.S. Geological Survey Open-File report $82-0933,34 \mathrm{p}$.

(P) D'Amore, F., and Truesde11, A., 1984, Helium in the Lardere110 geothermal fluid: Geothermics, v. 13, p. 227-239. 
(P) D'Amore, F., and Truesdell, A. H., 1985, Calculation of geothermal reservoir temperatures and steam fractions from gas compositions: Geothermal Resources Council Transactions, v. 9, part I, p. 305-310.

(P) Dalrymple, G. B., Burke, R. M., and Birkeland, P. W., 1982, Note concerning $\mathrm{K}-\mathrm{Ar}$ dating of a basalt flow from the Tahoe-Tioga interglaciation Sawmill Canyon, southeastern Sierra Nevada, California: Quaternary Research, v. 17, p. 120-122.

(P) Daniel, R. G., and Boore, D. K., 1982, Anomalous shear wave delays and surface wave velocities at Yellowstone caldera, Wyoming: Journal of Geophysical Research, v. 87, p. 2731-2744.

(P) Daniels, J. J., Olhoeft, G. R., and scott, J. H., 1983, Interpretation of core and well log physical property data from drill hole UPH-3, Stephenson County, Illinois: Journal of Geophysical Research, v. 88, p. 7346-7345.

(A) Davis, P. M., Parker, E. C., Dahlheim, H., Evans, J. R., Iyer, H. M., and Olsen, K. H., 1984, Teleseismic investigation of deep velocity structure beneath the Rio Grande Rift (abs.): Eos, Transactions American Geophysical Union, v. 65, p. 986.

(P) Dawson, P. B., Rodriguez Da Silva, A. H., Iyer, H. M., and Evans, J. R., 1985, Seismic study of the Agua de Pau geothermal prospect, Sao Miguel, Azores: Geothermal Resources Council Transactions, v. 9, part II, P. 401-406.

(A) Dawson, P. B., Evans, J. R., and Iyer, H. M., 1986, Preliminary results from teleseismic traveltime residuals in the Long Valley, California, region (abs.): Eos, Transactions American Geophysical Union, v. 67 , p. 1101 .

(0) Dawson, P. B., and Stauber, D. A., 1986, Data report for a threedimensional high-resolution P-velocity structural investigation of Newberry volcano, Oregon, using seismic tomography: U.S. Geological Survey Open-File Report 86-0352, $121 \mathrm{p}$.

(A) Deemer, S., Humphreys, M. C., Johnson, R. A., Smithson, S. B., Ellsworth, W. L., and Hill, D. P., 1984, Seismic reflection profiling through the Long Valley caldera (abs.): Eos, Transactions American Geophysical Union, v. 65, p. 985.

(A) Deemer, S., Humphreys, M. C., Johnson, R. A., Smithson, S. B., Ellsworth, W. L., and Hill, D. P., 1985, Structure of the Long Valley caldera interpreted from seismic reflection data (abs.): Eos, Transactions American Geophysical Union, v. 66, p. 301.

(P) Delaney, P. T., 1982, Rapid intrusion of magma into wet rock: groundwater flow due to pore pressure increases: Journal of Geophysical Research, v. 87, p. 7739-7756.

(A) Delaney, P. T., 1985, Heat-transfer theory applied to mafic dyke intrusion (abs.): Abstracts, International Conference on Mafic Dyke Swarms, University of Toronto, p. 34-36.

(A) Delaney, P. T., 1986, Temperature-dependent thermal properties of rocks and maximum temperatures at the contacts of intrusions (abs.):

Geological Society of America Abstracts with Programs, v. 18, p. 351 .

(P) Delaney, P. T., and Pollard, D. D., 1982, Solidification of basaltic magma during flow in a dike: American Journal Science, v. 282, p. 856-885.

(A) Delaney, P. T., Pollard, D. D., and Ziony, J. I., 1983, Dikes as indicators of stress direction: the influence of regional joints on the Colorado Plateau (abs.): Eos, Transactions American Geophysical Union, v. 64, p. 857 .

(P) Delaney, P. T., Pollard, D. D., Ziony, J. I., and KcKee, E. H., 1986, Field relations between dikes and joints: Emplacement processes and paleostress analysis: Journal of Geophysical Research, v. 91 , p. 4920-4938. 
(P) Denlinger, R. P., and Bufe, C. G., 1982, Reservoir conditions related to induced seismicity at The Geysers steam reservoir, northern California: Seimological Society of America Bulletin, v. 72, p. 1317-1327.

(P) Denlinger, R. P., and Riley, F., 1984, Deformation of Long Valley caldera, Mono County, California, from 1975 to 1982: Journal of Geophysical Research, v. 89, p. 8303-8314.

(P) Denlinger, R. P., Riley, F. S., Boling, J. K., and Carpenter, M. C., 1985, Deformation of Long Valley caldera between August 1982 and August 1983: Journal of Geophysical Research, v. 90, p. 11,199-11,209.

(P) DesMarais, D. J., Stallard, M. L., Nehring, H. L., and Truesdel1, A. H., 1982, Hydrocarbon production in the Cerro Prieto Geothermal Field: Proceedings of 4th Symposium on the Cerro Prieto Geothermal Field, Baja California, Mexico, Guadalajara, Mexico, August 10-12, 1982, p. 501-508.

(P) Diment, W. H., and Urban, T. C., 1982, Temperature changes with time in the slotted interval of a deep, shut-in geothermal well near thermal equilibrium: East Mesa 31-1, Imperial County, California, 1977-1982: Geothermal Resources Council Transactions, v. 6, p. 249-252.

(P) Diment, W. H., and Urban, T. C., 1983, A simple method for detecting anomalous fluid motions in boreholes from continuous temperature logs: Geothermal Resources Council Transactions, v. 7, p. 485-490.

(P) Diment, W. H., Urban, T. C., and Nathenson, M., 1985, Temperature variation with time in a perennially boiling well in the Long Valley caldera, Mono County, California; observations in Chance No. 1 (1976-1983): Geothermal Resources Council Transactions, v. 9, part I, P. 417-422.

(P) Doe, B. R., Leeman, W. P., Christiansen, R. L., and Hedge, C. E., 1982, Lead and strontium isotopes and related trace elements as genetic tracers in the upper Cenozoic rhyolite-basalt association of the Yellowstone Plateau volcanic field: Journal of Geophysical Research, v. 87, p. 4785-4806.

(A) Donahoe, R. J., Hemingway, B. S., and Liou, J. G., 1984, Zeolite stability in tuffaceous sediments at Searles Lake, California (abs.): Geological Society of America Abstracts with Programs, v. 16, no. 6, p. 492.

(A) Donnelly-Nolan, J. M., 1983, Diverse origins of thermal waters in the Geysers-Clear Lake geothermal area, northern California, USA (extended abs.): Extended Abstracts of the Fourth International Symposium on Water-Rock Interaction, Misasa, Japan, 1983, p. 123-126.

(A) Donne1ly-Nolan, J. M., 1983, Structural trends and geothermal potential at Medicine Lake Volcano, northeastern California (abs.): Eos, Transactions American Geophysical Union, v. 64, p. 898.

(A) Donnelly-Nolan, J. M., 1983, Two ash-flow tuffs and the stratigraphy of Medicine Lake Volcano, northern California Cascades (abs.): Geological Society of America Abstracts with Programs, v. 15, no. 5, p. 330 .

(A) Donnelly-Nolan, J. M., 1985, Geothermal potential of Medicine Lake Volcano, in Guffanti, M., and Muffler, L. J. P, eds., 1985, Proceedings of the workshop on geothermal resources of the Cascade Range: U.S. Geological Survey Open-File Report 85-521, p. 34-36.

(A) Donnelly-Nolan, J. M., 1986, Medicine Lake volcano, California, and its geothermal potential (abs.), in USGS Research on Energy Resources 1986, Program and Abstracts: U.S. Geological Survey Circular 974, p. 12-13. 
(P) Donnelly-Nolan, J. M., and Nolan, K. M., 1986, Catastrophic flooding and eruption of ash-flow tuff at Medicine Lake volcano, California: Geology, v. 14, p. 875-878.

(A) Druitt, T. H., and Bacon, C. R., 1985, Compositional and thermal zonation in the magma chamber of Mt. Mazama, Oregon (abs.): Eos, Transactions American Geophysical Union, v. 66, p. 1142.

(P) Druitt, T. H., and Bacon, C. R., 1986, Lithic breccia and ignimbrite erupted during the collapse of Crater Lake caldera, Oregon: Journal of Volcanology and Geothermal Research, v. 29, p. 1-32.

(P) Duffield, W. A., 1983, Geologic framework for geothermal energy in the Cascade Range: Geothermal Resources Council Transactions, v. 7, p. 243-246.

(P) Duffield, W. A., Bacon, C. R., and Delaney, P. T., 1986, Deformation of poorly consolidated sediment during shallow emplacement of a basalt sil1, Coso Range, California: Bulletin of Volcanology, v. 48, p. 97-107.

(P) Duffield, W. A., Christiansen, R. L., Koyanagi, R. Y., and Peterson, D. W., 1982, Storage, migration, and eruption of magma at Kilauea Volcano, Hawail, 1971-1972: Journal of Volcanology and Geothermal Research, v. 13, p. 273-307.

(P) Duffield, W. A., and Guffanti, M., 1982, The Geothermal Research Program of the U.S. Geological Survey: U.S. Geological Survey Circular 862, $15 \mathrm{p}$.

(P) Duffield, W. A., and McKee, E. H., 1986, Geochronology, structure, and basin-range tectonism of the Warner Range, northestern California: Geological Society of America Bulletin, v. 97, p. 142-146.

(0) Duffield, W. A., and Muffler, L. J. P., 1984, Geothermal resources of são Miguel Island, Azores, Portugal: U.S. Geological Survey Open-File Report 84-287, $21 \mathrm{p}$.

(P) Duffield, W. A., Tilling, R. I, , and Canul, R., 1984, Geology of El Chichon volcano, Chiapas, Mexico: Journal of Volcanology and Geothermal Research, v. 20, p. 117-132.

(P) Dungan, M. A., Grove, T. L., and Hildreth, W., eds., 1984, Proceedings of the Conference on Open Magmatic Systems, Ranchos de Taos, New Mexico: Southern Methodist University, $181 \mathrm{p}$.

(A) Dvorak, J. J., Okamura, A. T., and Sako, M. K., 1985, Summit magma reservoir at Mauna Loa volcano, Hawaii (abs.): Eos, Transactions American Geophysical Union, v. 66, p. 851.

(A) Eberhart-Phillips, D., 1983, Seismicity in the Clear Lake area, California, (abs.): Geological Society of America Abstracts with Programs, v. 15 , no. 5, p. 279 .

(A) Eberhart-Phillips, D., and Oppenheimer, D. H., 1983, Induced seismicty at The Geysers geothermal area, California (abs.): American Association of Petroleum Geologists 58th Annual Meeting. Pacific Section, Programs and Abstracts, Sacramento, California.

(P) Eberhart-Phillips, D. and Oppenheimer, D. H., 1984, Induced seismicity in The Geysers geothermal area, California: Journal of Geophysical Research, v. 89, p. 1191-1207.

(P) Eichelberger, J. C., and Hildreth, W., 1986, Research drilling at Katmai, Alaska: Eos, Transactions American Geophysical Union, v. 67. p. 778-780.

(P) Eichelberger, J. C., Lysne, P. C., Miller, C. D., and Younker, L. W., 1985, Research drilling at Inyo Domes, California: 1984 results: Eos, Transactions American Geophysical Union, v. 66, p. 186-187.

(A) Eichelberger, J. C., Lysne, P. C., Miller, C. D., and Younker, L. W., 1985, 1984 Drilling results at Inyo Domes, California (abs.): Eos, Transactions American Geophysical Union, v. 66, p. 384. 
(P) Elston, W. E., 1984, Mid-tertiary ash flow tuff cauldrons, southwestern New Mexico: Journal of Geophysical Reaserch, v. 89, p. 8733-8750.

(A) England, P. C., Sonder, L. J., Christiansen, R. L., and Wernicke, B. P., 1985. Thermal and mechanical investigations of Basin and Range deformation (abs.): Abstract 37 in Continental Extensional Tectonics, University of Durham, England, April 1985.

(P) Evans, J. R., 1982, Compressional wave velocity structure of the upper $350 \mathrm{~km}$ under the eastern Snake River Plain near Rexburg, Idaho: Journal of Geophysical Research, v. 87, p. 2654-2670.

(A) Evans, J. R., 1983, Compressional-wave velocity structure of Medicine Lake volcano and vicinity from teleseismic relative travel time residuals (abs.): Geophysics, v. 48, p. 478 (Extended version printed in the Technical Program of the 52nd Annual International Meeting of the Society of Exploration Geophysicists, 1982, Dallas, TX, p. 482-485)..

(P) Evans, J. R., and Allen, S. S., 1983, A teleseism-specific detection algorithm for single short-period traces: Seismological Society of America Bulletin, v. 73, p. 1173-1186.

(A) Evans, J. R., Berge, P.A., and Zucca, J. J., 1986, High-resolution active seismic tomography of Medicine Lake volcano, northern California (abs.): Earthquake Notes, v. 57, p. 10.

(A) Evans, J. R., and Iyer, H. M., 1982, Compressional-wave velocity structure of the Yellowstone-Snake River Plain system to a depth of $300 \mathrm{~km}$ : fundamental constraints on system models (abs.): Earthquake Notes, v. 54, p. 53.

(A) Evans, J. R., Stauber, D. A., and Dawson, P. B., 1986, Prospecting for shallow magma chambers in the Cascade Range using seismic tomography (abs.), in USGS Research on Energy Resources - 1986, Program and Abstracts: U.S. Geological Survey Circular 974, p. 15-16.

(P) Farrar, C. D., and Sorey, M. L., 1985, Monitoring the hydrothermal system in Long Valley caldera, California: Geothermal Resources Council Transactions, v. 9, part I, p. 423-428.

(0) Farrar, C. D., Sorey, M. L., Rojstaczer, S. A., Janik, C. J., Mariner, R. H., Winnett, T. L., and Clark, K. D., 1985, Hydrologic and geochemical monitoring in Long Valley caldera, Mono County, California: U.S. Geological Survey Water-Resources Investigations Report 85-4183, $137 \mathrm{p}$.

(P) Fierstein, J., 1984, The Valley of Ten Thousand Smokes: Alaska Natural History Association, $16 \mathrm{p}$.

(A) Fierstein, J., and Hildreth, W., 1984, Grain-size study of the pyroclastic deposits of Novarupta, Katmai National Park, Alaska (abs.): Eos, Transactions American Geophysical Union, v. 65, p. 1149.

(A) Fierstein, J., and Hildreth, W., 1986, Ejecta dispersal and dynamics of the 1912 eruptions at Novarupta, Katmai National Park, Alaska (abs.): Eos, Transactions American Geophysical Union, v. 67, p. 1246.

(A) Fink, J. H., Pollard, D. D., and Donnelly-Nolan, J., 1982, Structural relationships among feeder dikes, silicic domes, and ground cracks in the Medicine Lake Highland and Mt. St. Helens Volcanoes (abs.): Eos, Transactions American Geophysical Union, v. 63, p. 1143.

(0) Finn, C., 1982, Complete Bouguer gravity map near Crater Lake, Oregon: U.S. Geological Survey Open-File report $82-592,1$ sheet, scale $1: 62,500$.

(0) Finn, C., 1982, Principal facts for gravity stations near Crater Lake, Oregon: U.S. Geological Survey Open-File report 82-484, 6 p.

(0) Finn, C., 1982, Principal facts for seventy-four gravity stations in the northern California Cascade Mountains: U.S. Geological Survey Open-File Report 82-1080, 7p. 
(0) Finn, C., 1983, Principal facts for sixty-nine gravity stations near the Mt. Jefferson Wilderness area, Oregon: U.S. Geological Survey Open-File Report 83-466, 7p.

(A) Finn, C., 1985, A magnetic study of Mt. St. Helens, Washington (abs.): Eos, Transactions American Geophysical Union, v. 66, p. 870.

(A) Finn, C., 1985, Gravity and magnetic studies in the Cascade Range, in Guffanti, M., and Muffler, L. J. P, eds., 1985, Proceedings of the workshop on geothermal resources of the Cascade Range: U.S. Geological Survey Open-File Report 85-521, p. 56-58.

(0) Finn, C., Phillips, W. M., and Williams, D. L., 1984, Gravity maps of the State of Washington and adjacent areas: U.S. Geological Survey Open-File Report 84-416, scale 1:250,000, 6p., 18 sheets.

(P) Finn, C., and Williams, D. L., 1982, Gravity evidence for a shallow intrusion under the Medicine Lake volcano, California: Geology, v. 10 , p. 503-507.

(P) Finn, C. and Williams, D., 1983, Gravity studies in the Cascade Range: Geothermal Resources Council Transactions, v. 7, p. 247-251.

(A) Finn, C. and Williams, D. L., 1983, Regional interpretation of gravity data from the Cascade Range (abs.): Eos, Transactions American Geophysical Union, v. 64, p. 886.

(0) Fitterman, D. V., 1982, Computer program SPDIKE for calculation of self-potential anomalies near vertical dikes: U.S. Geological Survey Open-File report $82-470,45 \mathrm{p}$.

(A) Fitterman, D. V., 1983, Results of time-domain electromagnetic soundings at Newberry Volcano, Oregon (abs.): Eos, Transactions American Geophysical Union, v. 64, p. 899.

(0) Fitterman, D. V., 1983, Time-domain electromagnetic soundings of Newberry Volcano, Deschutes County, Oregon: U.S. Geological Survey Open-File Report 83-832, 64p.

(A) Fitterman, D. V., and Anderson, W. L., 1985, Effect of transmitter turnoff characteristics on transient soundings (abs.): Geophysics, v. 50, p. 272 (Extended version printed in Technical Program of the 54th Annual International Meeting of the Society of Exploration Geophysicists, 1984, Atlanta, GA).

(A) Fitterman, D. V., Bisdorf, R. J., Stanley, W. D., and Zohdy, A. A. R., 1986, Geothermal significance of an extensive conductor beneath Newberry volcano, Oregon (abs.), in USGS Research on Energy Resources - 1986, Program and Abstracts: U.S. Geological Survey Circular 974, p. 16 .

(P) Fitterman, D. V., and Corwin, R. F., 1982, Inversion of self-potential data from the Cerro Prieto geothermal field, Mexico: Geophysics, v. 47 , p. $938-945$.

(0) Fitterman, D. V., and Grette, R. O., 1983, Self-potential measurements at Newberry Crater, Oregon: U.S. Geological Survey Open-File Report 83-909, 11p.

(P) Fitterman, D. V., and Neev, D. K., 1985, Transient sounding investigation of Newberry volcano, Oregon: Geothermal Resources Council Transactions, v. 9, part II, p. 407-410.

(0) Fitterman, D. V., Neev, D. K., Bradley, J. A., and Grose, C. T., 1985, Hore time-domain electromagnetic soundings of Newberry Volcano, Deschutes County, Oregon: U.S. Geological Survey Open-File Report 85-451, $77 \mathrm{p}$.

(P) Flanagan, G., and Williams, D. L., 1982, A magnetic investigation of Mount Hood, Oregon: Journal of Geophysical Research, v. 87, p. 2804-2814.

(P) Fleischer, M., Wilcox, R. E., and Matzko, J. J., 1984, Microscopic determination of the non-opaque minerals: U.S. Geological Survey Bulletin $1627,453 \mathrm{p}$. 
(A) Fournier, R. 0., 1982, A method of calculating quartz solubilties in aqueous sodium chloride solutions above $100^{\circ} \mathrm{C}$ (abs.): Proceedings of The International Symposium on Hydrothermal Reactions, Yokahama, Japan, p. 332 .

(P) Fournier, R. O., 1982, Geochemistry in geothermal exploration and production: Proceedings of Pacific Geothermal Conference 1982 incorporating the 4th New Zealand Geothermal Workshop, p. 209-215.

(P) Fournier, R. O., 1983, A method of calculating quartz solubilities in aqueous sodium chloride solutions: Geochimica et Cosmochimica Acta, v. 47 , p. 579-586.

(P) Fournier, R. 0., 1983, Active hydrothermal systems as analogues of fossil systems: in The role of heat in the development of energy and mineral resources in the northern Basin and Range province, Geothermal Resources Council, Special Report no. 13, p. 263-284.

(A) Fournier, R. 0., 1983, Self-sealing and brecciation resulting from quartz deposition within hydrothermal systems (extended abs.): Extended Abstracts, 4th International Symposium on Water-Rock Interactions, 1983, Misasa, Japan, p. 137-140.

(A) Fournier, R. 0., 1983, Yellowstone National Park as an opportunity for continental drilling in thermal regions (abs.): Geological Society of America Abstracts with Programs, v. 15, no. 5, p. 434.

(A) Fournier, R. 0., 1984, Geochemistry of hydrothermal brines (abs.): Program, 113th AIME Annual Meeting, Los Angeles, p. 41.

(A) Fournier, R. 0., 1984, Objectives for continental scientific drilling in Yellowstone National Park (abs.): Eos, Transactions American Geophysical Union, v. 65, p. 1095.

(P) Fournier, R. O., and Hanshaw, B. B., 1986, Geochemical evaluation of the geothermal resources in the San Marcos region, Guatemala: Applied Geochemistry, v. 1, p. 189-197.

(P) Fournier, R. O., Hanshaw, B. B., and Urrutia Sole, J. F., 1982, Oxygen and hydrogen isotopes in thermal waters at Zunil, Guatemala: Geothermal Resources Council Transactions, v. 6, p. 89-91.

(A) Fournier, R. O., and Marshal1, W. L., 1982, Calculation of amorphous silica solubilities and cation hydration number in aqueous salt solutions using the concept of effective density of water (abs.): Proceedings of The International Symposium on Hydrothermal Reactions, Yokahama, Japan, p. 333.

(P) Fournier, R. O., and Marshall, W. L., 1983, Calculation of amorphous silica solubilities at $25^{\circ}$ to $300^{\circ} \mathrm{C}$ and apparent cation hydration numbers in aqueous salt solutions using the concept of effective density of water: Geochimica et Cosmochimica Acta, v. 47, p. 587-596.

(P) Fournier, R. O., and Pitt, A. M., 1985, The Yellowstone magamatichydrothermal system, U.S.A.: Geothermal Resources Council, 1985 International Symposium on Geothermal Energy, International Volume, p. 319-327.

(P) Fournier, R. O., and Potter, R. W., II, 1982, A revised and expanded silica (quartz) geothermometer: Geothermal Resources Council Bulletin, v. 11, no. 10, p. 3-9.

(A) Fournier, R. O., and Potter, R. W., II, 1982, An equation correlating the solubility of quartz in water from $25^{\circ}$ to $900^{\circ} \mathrm{C}$ at pressures up to 10,000 bars(abs.): Proceedings of The International Symposium on Hydrothermal Reactions, Yokahama, Japan, p. 334.

(P) Fournier, R. O., and Potter, R. W., II, 1982, An equation correlating the solubility of quartz in water from $25^{\circ}$ to $900^{\circ} \mathrm{C}$ at pressures up to 10,000 bars: Geochimica et Cosmochimica Acta, v. 46, p. 1969-1973. 
(P) Fournier, R. O., Rosenbauer, R. J., and Bischoff, J. L., 1982, The solubility of quartz in aqueous sodium chloride solution at $350^{\circ} \mathrm{C}$ and 180 to 500 bars: Geochimica et Cosmochimica Acta, v. 46, p. 1975-1978.

(P) Fournier, R. O., and Thompson, J. M., 1982, An isotopic study of the Coso, California, geothermal area: Geothermal Resources Council Transactions, v. 6, p. 85-87.

(A) Fournier, R. O., Thompson, J. M., and Hutchinson, R. A., 1986, Fluctuations in composition of Cistern Spring, Norris Geyser Basin, Yellowstone National Park, Wyoming -- Variable boiling and mixing 1962-1985 (abs.): Fifth International Symposium on Water-Rock Interaction Extended Abstracts, Reykjavik, Iceland, August, 1986 , p. 206-209.

(0) Frazer, D. C., 1983, Airborne electromagnetic surveys of the Cascade Range, western United States with a preface by D. B. Hoover: U.S. Geological Survey Open-File Report 83-92, 64p., 30 sheets.

(P) Friedman, I., Long, W., 1984, Volcanic glasses, their origins and alteration processes: Journal of Non-crystalline Solids, v. 67, p. 127-133.

(P) Friedman, J. D., Williams, D. L., and Frank, D., 1982, Structural and heat flow implications of infrared anomalies at Mt. Hood, Oregon, 1972-1977: Journal of Geophysical Research, v. 87, p. 2793-2803.

(A) Frischknecht, F. C., Anderson, W. L., and Raab, P. V., 1983, Electromagnetic soundings on the Medicine Lake Volcano, California (abs.): Eos, Transactions American Geophysical Union, v. 64, p. 899.

(P) Fuis, G. S., and Kohler, W. M., 1984, Crustal structure and tectonics of the Imperial Valley region, California: Society of Economic Paleontologists and Mineralogists, Pacific Section, v. 40, p. 1-13.

(P) Fuis, G. S., Mooney, W. D., Healy, J. H., McMechan, G. A., and Lutter, W., 1982, Crustal structure of the Imperial Valley region, in The Imperial Valley, California, Earthquake of October 15, 1979: U.S. Geological Survey Professional Paper 1254, p. 25-49.

(P) Fuis, G. S., Mooney, W. D., Healy, J. H., McHechan, G. A., and Lutter, W. J., 1984, A seismic refraction study of the Imperial Valley region, California: Journal of Geophysical Research, v. 89, p. 1165-1189.

(P) Fuis, G. S., and Zucca, J. J., 1984, A geologic cross section of northeastern California from seismic refraction results, in Nilsen, T. H., ed., Geology of the Upper Cretaceous Hornbrook Formation, Oregon and California: Pacific Section, Society of Economic Paleontologists and Mineralogists, v. 42, p. 203-209.

(A) Fuis, G. S., Walter, A. W., Mooney, W. D., and McCarthy, J., 1986, Crustal velocity structure of the Salton Trough, western Mojave desert, and Colorado desert, from seismic refraction (abs.): Geological Society of America Abstracts with Programs, v. 18, no. 2, p. 107.

(A) Fuis, G. S., Zucca, J. J., Mooney, W. D., and Milkereit, B., 1983, Crustal structure of the Klamath, Cascade and Modoc regions of northeastern California from seismic-refraction data (abs.): Eos, Transactions American Geophysical Union, v. 64, p. 886.

(A) Garcia, M. O., Byers, C. D., Wolfe, E. W., and Rhodes, J. M., 1984, Chemistry and mineralogy of lavas from the continuing eruption of Kilauea volcano, Hawaii (abs.): Eos, Transactions American Geophysical Union, v. 65, p. 1130.

(A) Gardner, C. A., and Miller, C. D., 1985, Secular variation paleomagnetic studies of silicic domes, Inyo volcanic chain, California (abs.): Eos, Transactions American Geophysical Union, v. 66, p. 1142. 
(A) Gartner, A. E., and Delaney, P., 1985, Dominantly horizontal propagation directions of diabasic dikes, San Rafael Dessert region, Utah (abs.): Eos, Transactions American Geophysical Union, v. 66, p. 1145.

(A) Ghose, S., Hewat, A. W., Marezio, M., Dang, N. V., Robie, R. A., and Evans, H. T., Jr., 1984, Electron and spin ordering and associated phase transitions in ilvaite, a mixed valance iron silicate (abs.): Acta Crystallographica, v. 140 , p. C263.

(P) Giggenbach, W. F., Gonfiantini, R., Jangi, B. L., and Truesdell, A. H., 1983, Isotopic and chemical compositions of Parbati Valley geothermal discharges, northwest Himalaya, India: Geothermics, v. 12, p. 199-222.

(P) Goff, F., Shevenell, L., Janik, C. J., Truesdell, A. H., Grigsby, C. 0., and Paredes, R., 1986, Hydrogeochemistry and preliminary reservoir model of the Platanares geothermal sysytem, Honduras, Central America: Geothermal Resources Council Transactions, v. 10, p. 125-130.

(P) Goyal, K. P., Halfman, S. E., Truesde11, A. H., and Howard, J. H., 1982, Production characteristics of some Cerro Prieto wells: Proceedings of 4th Symposium on the Cerro Prieto Geothermal Field, Baja California, Mexico, Guadalajara, Mexico, August 10-12, 1982, p. 317-329.

(P) Grant, M. A., Truesdel1, A. H., and Mañón, A., 1984, Production induced boiling and cold water entry in the Cerro Prieto geothermal reservoir indicated by chemical and physical measurements: Geothermics, v. 13, p. 117-140.

(P) Grose, T. L. T., and McKee, E. H., 1986, Potassium-argon ages of late Miocene to late Quaternary volcanic rocks in the Susanville-Eagle Lake area, Lassen County, California: Isochron West, v. 45, p. 5-11.

(A) Grove, T. L., Baker, M. B., Champion, D. E., and Donnelly-Nolan, J., 1984, The role of assimilation and fractional crystallization in the compositionally zoned Giant and Chimney Craters eruption, Medicine Lake Volcano, California (abs.): Eos, Transactions American Geophysical Union, v. 65, p. 1153.

(A) Grove, T. L., Baker, M. B., and Donnelly-Nolan, J., 1984, The influence of crustal assimilation in the evolution of calc-alkaline series lavas, in Dungan, M. A., Grove, T. L., and Hildreth, Wes, eds., Proceedings of the Conference on Open Magmatic Systems, Ranchos de Taos, New Mexico: Southern Methodist University, p. 57-59.

(A) Grove, T. L., Baker, M. B., and Donnelly-Nolan, J. M., 1985, Quantitative estimates of assimilation and fractional crystallization (AFC) in calc-alkaline systems (abs.): Geological Society of America Abstracts with Programs, v. 17, p. 599.

(A) Grove, T. L., Baker, M. B., Kinzler, R. J., and Donnelly-Nolan, J. M., 1986, Mineralogical evidence of magmatic processes at Medicine Lake Highland, M. California, a convergent margin calc-alkaline volcanic system (abs.): International Mineralogical Association 14 th general meeting Abstracts with Program, p. 115.

(A) Grove, T. L., and Donnelly-Nolan, J., 1983, Role of amphibole in the differentiation history of Medicine Lake Highland lavas (abs.): Eos, Transactions American Geophysical Union, v. 64, p. 900.

(A) Gudmundsson, J. S., and Janik, C. J., 1986, Isotope monitoring in Svartsengi geothermal field (abs.): Fifth International symposium on Water-Rock Interaction Extended Abstracts, Reykjavik, Iceland, August, 1986, p. 244-247. 
(A) Guffanti, M., 1985, Previous estimates by the U.S. Geological Survey of geothermal resources of the Cascade Range, in Guffanti, $M$. , and Muffler, L. J. P, eds., 1985, Proceedings of the workshop on geothermal resources of the Cascade Range: U.S. Geological Survey Open-File Report 85-521, p. 10-13.

(P) Guffanti, M. and Muffler, L. J. P., 1985, Geothermal resources of the Cascades: USGS workshop: Eos, Transactions American Geophysical Union, v. 66, p. 722-723.

(0) Guffanti, M. and Muffler, L. J. P, eds., 1985, Proceedings of the workshop on geothermal resources of the Cascade Range: U.S. Geological Survey Open-File Report 85-521, 85p.

(A) Guffanti, H., and Weaver, C. S., 1986, Distribution of Late Cenozoic volcanic vents in the Cascade Range and northwestern Basin and Range Province (abs.): Bos, Transactions American Geophysical Union, v. 67, p. 1226 .

(P) Gupta, H. K., Ward, R. W., and Lin, T-L., 1982, Seismic wave velocity investigation at The Geysers-Clear Lake geothermal field, California: Geophysics, v. 47, P. 819-824.

(A) Haas, J. L., Jr., 1984, Thermodynamic properties of the oxygen-buffer phases: A critical evaluation using computer-aided methods (abs.): International Union for Pure and Applied Chemistry, 39th Calorimetry Conference, Program and Abstract of papers, Hamilton, Canada, p. 92.

(A) Haas, J. L., Jr., 1986, The enhanced value of physical and chemical properties derived from large chemical networks (abs.): Eos, Transactions American Geophysical Union, v. 67, p. 357.

(0) Hadley, D. M., and Cavit, D. S., 1982, Statistical study of seismicity associated with geothermal reservoirs in California: U.S. Geological Survey Open-File Report 82-1068, 89p.

(P) Hagstrum, J. T., and Lipman, P. W., 1986, Paleomagnetism of the structurally deformed Latir volcanic field, northern New Mexico: Relations to formation of the Questa caldera and development of the Rio Grande Rift: Journal of Geophysical Research, v. 91, p. 7383-7402.

(A) Harmon, R. S., Nehring, N. L., Motyka, R. J., White, L. D., and Borthwick, J., 1983, Hydrogen and oxygen isotopic composition of fumarole condensates from the Augustine volcano, Alaska (extended abs.): Extended Abstracts, 4th International Symposium on Water-Rock Interaction, Misasa, Japan, 1983, p. 169-171.

(A) Hearn, B. C., Jr., McLaughl in, R. J., and Donnelly-Nolan, J. M., 1983, Tectonic framework of Clear Lake Basin, California (abs.):

Geological Society of America Abstracts with Programs, v. 15, no. 5, p. 278.

(A) Helz, R. T., 1986, Diapiric transfer of melt in Kilauea Iki lava lake, Hawaii (abs.): Geological Association of Canada Program with Abstracts, v. 11, p. 80 .

(0) Helz, R. T., Banks, N. G., Casadevall, T. J., Fiske, R. S., and Moore, R. B., 1984, A catalogue of drill core recovered from Kilauea Iki lava lake from 1967 to 1979: U.S. Geological Survey Open-File Report 84-0484, 72p.

(P) Henley, R. W., Truesdell, A. H., and Barton, P. B., Jr., with a contribution by J. A. Whitney, 1984, Fluid-mineral equilibria in hydrothermal systems, v. 1 of Reviews in Economic Geology, 268 p.

(0) Herkelrath, W. N., and Moench, A. F., 1982, Laboratory investigations of the physics of steam flow in a porous medium: U.S. Geological survey Open-File report 82-0095, $42 \mathrm{p}$.

(P) Herkelrath, W. N., Moench, A. F., and $0^{\prime}$ Neal, C. F., II, 1983, Laboratory investigations of steam flow in a porous medium: Water Resources Research, v. 19, p. 931-937. 
(P) Hildreth, W., 1983, The compositionally zoned eruption of 1912 in the Valley of Ten Thousand Smokes, Katmai National Park, Alaska: Journal of Volcanology and Geothermal Research, v. 18 , p. 1-56.

(A) Hildreth, W., 1985, The Bishop tuff; trace contents of dark pumice (abs.): Geological Society of America Abstracts with Programs, v.17, no. 6, p. 361 .

(A) Hildreth, W., Christiansen, R. L., and O'Weil, J. R., 1983, Catastrophic isotopic modification of rhyolitic magma at times of caldera subsidence, Yellowstone Plateau (abs.): Eos, Transactions American Geophysical Union, v. 64, p. 882.

(P) Hildreth, W., Christiansen, R. L., and O'Neil, J. R., 1984, Catastrophic isotopic modification of rhyolitic magma at times of caldera subsidence, Yellowstone Plateau volcanic field: Journal of Geophysical Research, v. 89, p. 8339-8369.

(A) Hildreth, W., and Fierstein, J., 1983, Mount Adams volcano and its 30 "parasites" (abs.): Geological Society of America Abstracts with Programs, v. 15 , no. 5, p. 331 .

(A) Hildreth, W., and Fierstein, J., 1985, Mount Adams: eruptive history of an andesite-dacite stratovolcano at the focus of a fundamentally basaltic volcanic field, in Guffanti, M., and Muffler, L. J. P, eds., 1985, Proceedings of the workshop on geothermal resources of the Cascade Range: U.S. Geological Survey Open-File Report 85-521, p. 44-50.

(A) Hildreth, W., and Fierstein, J., 1986, Near-vent ejecta around Novarupta, eruption of 1912, Katmai National Park, Alaska (abs.): Eos, Transactions American Geophysical Union, v. 67, p. 1246.

(P) Hildreth, W., Grove, T. L., and Dungan, H. A., 1986, Introduction to special section on open magmatic systems: Journal of Geophysical Research, v. 91, p. 5887-5889.

(A) Hildreth, W., and Mahood, G. A., 1984, Ring-fracture eruption of the Bishop Tuff indicated by accidental lithic fragments (abs.): Eos, Transactions American Geophysical Union, v. 65, p. 1149.

(P) Hildreth, W., and Mahood, G. A., 1985, Correlation of ash-flow tuffs: Geological Society of America Bulletin, v. 96, p. 968-974.

(P) Hildreth, W.and Mahood, G. A., 1986, Ring-fracture eruption of the Bishop tuff: Geological Society of America Bulletin, v. 97, p. 396-403.

(0) Hill, D. P., Bailey, R. A., and Ryall, A. S., eds., 1984, Active tectonic and magmatic processes beneath Long Valley caldera, eastern California: U.S. Geological Survey Open-File Report 84-939, 942p..

(P) Hill, D. P., Bailey, R. A., and Ryall, A. S., 1985, Active tectonic and magmatic processes beneath Long Valley caldera, eastern California: an overview: Journal of Geophysical Research, v. 90, p. 11,11111,120 .

(0) Hil1, D. P., Kissling, E., Luetgert, J. H., and Kradolfer, U., 1984, Constraints on the upper crustal structure of the Long Valley-Mono Craters volcanic complex, eastern California, from seismic refraction measurements, in Hill D. P., Bailey, R. A., and Ryall, A. S., eds., Active tectonic and magmatic processes beneath Long Valley caldera, eastern California: U.S. Geological Survey Open-File Report 84-939, p. 151-187.

(P) Hi11, D. P., Kissling, E., Luetgert, J. H., and Kradolfer, U., 1985, Constraints on the upper crustal structure of the Long Valley-Mono Craters volcanic complex, eastern California, from seismic refraction measurements: Journal of Geophysical Research, v. 90, p. $11,135-11,150$. 
(0) Hill, D. P., Ryall, A. S., and Bailey, R. A., 1984, Active tectonic and magmatic processes beneath Long Valley caldera, eastern California: a summary, in Hill D. P., Bailey, R. A., and Ryall, A. S., eds., Active tectonic and magmatic processes beneath Long Valley caldera, eastern California: U.S. Geological Survey Open-File Report 84-939, p. 4-23.

(O) Hoover, D., Amaral, R., and Broker, M., 1983, Preliminary report on audio-magnetotelluric survey on São Miguel Island, Azores Portugal: U.S. Geological Survey Open-File Report 83-441, 111 p., 8 sheets.

(P) Hoover, D., Rodgrigues Da Silva, A., Pierce, H., and Amaral, R., 1984, The application of audio-magnetotelluric surveys on são Miguel Island, Azores, Portugal: Geothermal Resources Council Transactions, v. 8, P. 499-503.

(P) Hoover, D. B., Pierce, H. A., and Long, C. L., 1985, Is Island Park a hot dry rock system? Geothermal Resources Council Transactions, v. 9, part II, P. 25-29.

(0) Hoover, D. B., Pierce, H. A., Amaral, R., and Tippens, C., 1985, Preliminary report on electrical studies conducted during 1983 on são Miguel Island, Azores Portugal: U.S. Geological Survey Open-File Report 85-19, 75 p.

(0) Hoover, D. B., Tippens, C. L., and Cooke, J. E., 1982, Near surface resistivity variations on Kahoolawe Island, Hawaii: U.S. Geological Survey Open-File Report 82-146, 26p.

(P) Hutsinpiller, A., and Parry, W. T., 1985, Geochemistry and geothermometry of spring water from the Blackfoot reservoir region, southeastern Idaho: Journal of Volcanology and Geothermal Research, v. 26, p. 275-296.

(P) Ingebritsen, S. E., Carothers, W. W., Mariner, R. H., Gudmundsson, J. S., and Sammel, E. A., 1986, Flow testing of the Newberry 2 research drillhole, Newberry volcano, Oregon: U.S. Geological Survey Water-Resources Investigation 86-4133, $23 \mathrm{p}$.

(P) Ingebritsen, S. E., and Sorey, M. L., 1985, A quantitative analysis of the Lassen hydrothermal system, North Central California: Water Resources Research, v. 21, p. 853-868.

(A) Iyer, H. M., 1983, Geothermal seismic noise (abs.): IASPEI Symposium on Microseisms: International Union of Geodesy and Geophysics, XVIII Federal Assembly, Hamburg, Germany.

(P) Iyer, H. M., 1984, A review of crust and upper mantle structure studies of the Snake River Plain--Yellowstone volcanic system: A major lithospheric anomaly in the western U.S.A.: Tectonophysics, v. 105, p. 291-308.

(P) Iyer, H. M., 1984 , Geophysical evidence for the locations, shapes and sizes, and internal structure of magma chambers beneath regions of Quaternary volcanism: Philosophical Transactions of the Royal Society of London, Series A, v. 310, p. 473-510.

(A) Iyer, H. M., 1985, Characteristics of Cascades magmatic systems determined from teleseismic-residual studies, in Guffanti, M., and Muffler, L. J. P, eds., 1985, Proceedings of the workshop on geothermal resources of the Cascade Range: U.S. Geological Survey Open-File Report $85-521$, p. 53-55.

(A) Iyer, H. M., and Evans, J. R., 1982, Teleseismic traveltime anomaly at Mono and Inyo Craters, California: a dike-form low-velocity body? (abs.): Earthquake Notes, v. 54, p. 92. 
(A) Iyer, H. M., Rite, A., and Green, S. M., 1983, Search for geothermal heat sources in the Oregon Cascades by means of the teleseismic P-residual technique (abs.): Geophysics, v. 48, p. 478 (Extended version printed in the Technical Program of the 52nd Annual International Meeting of the Society of Exploration Geophysicists, 1982, Dallas, TX, p. 479-482).

(P) Jakobsson, S. P., and Moore, J. G., 1986, Hydrothermal minerals and alteration rates at Surtsey volcano, Iceland: Geological Society of America Bulletin, v. 97, p. 648-659.

(A) Jakobsson, S. P., and Moore, J. G., 1986, Basaltic tephra interaction with sea water: Evidence from the Surtsey drill core of 1979 (abs.): Fifth International Symposium on Water-Rock Interaction Extended Abstracts, Reykjavik, Iceland, August, 1986, p. 279-281.

(A) Janik, C. J., and Dobson, P. F., 1983, Thermodynamic, isotopic, and chemical evidence for equilibrium in the Los Azufres geothermal system (abs.): Geological Society of America Abstracts with Programs, v. 15, no. 6, p. 603.

(P) Janik, C. J., Nehring, H. L., Huebner, M. A., and Truesde11, A. H., 1982, Carbon-13 variations in fluids from the Cerro Prieto Geothermal System: Proceedings of 4th Symposium on the Cerro Prieto Geothermal Field, Baja California, Mexico, Guadalajara, Mexico, August 10-12, 1982 , p. 535-541.

(P) Janik, C. J., Nehring, N. L., and Truesde11, A. H., 1983, stable isotope geochemistry of thermal fluids from Lassen Volcanic National Park, California: Geothermal Resources Council Transactions, v. 7, p. 295-300.

(P) Janik, C. J., Truesde11, A. H., Sammel, E. A., and White, A. F., 1985, Chemistry of low-temperature geothermal waters at Klammath Falls, Oregon: Geothermal Resources Council Transactions, v. 9, part I, p. 325-331.

(0) Janik, C. J., Yee, Andrew, White, A. F., Stallard, M. L., Brown, A. P., Wheeler, M. C., Swanson, S. R., Winnett, T. L., and Fong, Grace, 1984, Chemical and isotope data on well discharges of the Klamath Falls geothermal system, in Benson, S. M., and others, Data from pumping and injection tests and chemical sampling in the geothermal aquifer at Klamath Falls, Oregon: U.S. Geological Survey Open-File Report 84-146, p. 90-97.

(A) Jarpe, S. P., Sanford, A. R., and Jaksha, L. H., 1984, Evidence for magmatic intrusion during an earthquake swarm in the central Rio Grande rift (abs.): Eos, Transactions American Geophysical Union, v. 65, p. 1001 .

(P) Kakas, K., Frischknecht, F., Ujszaszi, J., Anderson, W. L., and Pracser, E., 1985, Transient electromagnetic soundings, development of interpretation methods, and application to bauxite exploration: Geophysical Transactions Eotovos Lorand Geophysical Institute of Hungary, Budapest, v. 31, p. 295-310.

(0) Kauahikaua, J., Jackson, D. B., and Zablocki, C. J., 1983, Complete data listings for CSEM soundings on Kilauea Volcano, Hawaii: U.S. Geological Survey Open-File Report 83-66, 49 p.

(0) Keith, L. A., and Delaney, P. T., 1984, FORTRAN programs for properties of water and steam, and solubilities of solid silica phases: U.S. Geological Survey Open-File Report 84-690, 57 p.

(P) Keith, L. A., Delaney, P. T., and Moore, D. E., 1983, Permeability reduction due to precipitation of quartz under nonisothermal conditions: Proceedings Ninth Workshop on Geothermal Reservoir Engineering, Stanford University, Stanford, California, SGP-TR-74, p. 239-245. 
(A) Keith, T. E. C., 1983, Mineralogical and chemical changes in fumarolic deposits with time at surface conditions (extended abs.): Extended abstracts, Fourth International Symposium on Water-rock Interaction, Misasa, Japan, p. 231-234.

(A) Keith, T. E. C., 1985, Hydrothermal alteration in the Madera Limestone and Sandia Formation from corehole vc-1, Valles caldera, New Mexico (abs.): Eos, Transactions American Geophysical Union, v. 66, p. 1080 .

(A) Keith, T. E. C., 1985, Active hydrothermal alteration in the vicinity of the Novarupta dome, Valley of 10,000 Smokes, Alaska (abs.): Eos, Transactions American Geophysical Union, v. 66, p. 1154.

(A) Keith, T. E. C., 1986, Distribution of hydrothermal alteration associated with Novarupta caldera, Katmai National Park, Alaska (abs.): Eos, Transactions American Geophysical Union, v. 67, p. 1246.

(A) Keith, T. E. C., and Bargar, K. E., 1982, Hydrothermal alteration in core from drill hole Newberry 2, Oregon (abs.): Eos, Transactions American Geophysical Union, v. 63, p. 1128.

(P) Keith, T. E., C., Bargar, K. E., Howe, S. S., Carothers, W. W., and Barnes, Ivan, 1984, Mineralogical studies of the hydrothermal system in Newberry Volcano drill hole 2, Oregon: Geothermal Resources Council Transactions, v. 8, p. 125-128.

(P) Keith, T. E. C., Donnelly-Nolan, J. M., Markman, J. L., and Beeson, M. H., 1985, K-Ar ages of rocks in the Hount Hood area, Oregon: Isochron/West, no. 42, p. 12-16.

(P) Keith, T. E. C., Gannett, M. W., Eichelberger, J. C., and Waibel, A. F., 1986. Lithology and hydrothermal alteration of drill hole RDO-1, Newberry caldera, Oregon: Oregon Geology, v. 48, p. 103-107,110.

(P) Keith, T. E. C., Mariner, R. H., Bargar, K. E., Evans, W. C., and Presser, T. S., 1984, Hydrothermal alteration in Oregon's Newberry Volcano No. 2: fluid chemistry and secondary-mineral distribution: Geothermal Resources Council Bulletin, v. 13, no. 4, p. 9-17.

(P) Keith, T. E. C., Thompson, J. M., and Mays, R. E., 1983, Selective concentration of cesium in analcime during hydrothermal alteration, Yellowstone National Park, Wyoming: Geochimica et Cosmochimica Acta, v. 47, p. 795-804.

(A) Kendal1, C., Chou, I-M., Coplen, T. B., 1983, Salt effect on oxygen isotopic equilibria (abs.): Eos, Transactions American Geophysical Union, v. 64, p. 334-335.

(P) Kharaka, Y. K., and Carothers, W. W, 1986, Oxygen and hydrogen isotope geochemistry of deep basin brines: Chapter 8 in Fritz, P., and Fontes, J. C., eds., Handbook of Environmental Isotope Geochemistry, v. II, Elsevier, Amsterdam, p. 305-360.

(A) Kharaka, Y. K., Carothers, W. W., and Law, L. M., 1984, The influence of geological membranes on the chemical composition of subsurface waters (abs.): Clay Minerals Society Annual Meeting Proceedings, Baton Rouge, LA, P. 68.

(A) Kharaka, Y. K., Carothers, W. W., and Law, L. M., 1985, Origin of gaseous hydrocarbons in geopressured geothermal waters (abs.): in Dorfman, M. H., and Morton, R. A., eds., Proceedings, 6th U.S. Gulf Coast Geopressured-Geothermal Energy Conference, Pergamon Press, p. 160.

(P) Kharaka, Y. K., Carothers, W. W., and Rosenbauer, R. J., 1983, Thermal decarboxylation of acetic acid: Implications for origin of natural gas: Geochimica et Cosmochimica Acta, v. 47, p. 397-402.

(A) Kharaka, Y. K., Law, L. M., and Specht, D. J., 1983, Hydrodynamics, geochemistry, and metal transport of Gulf Coast brines (abs.): Geological Society of America Abstracts with Programs, v. 15, no. 6 , p. 612 . 
(A) Kharaka, Y. K., Specht, D. J., and Carothers, W. W., 1985, Low to intermediate temperatures calculated by chemcial geothermometers (abs.): American Association of Petroleum Geologists Bulletin, AAPG Annual Convention, v. 69, p. 273.

(A) Kieffer, S. W., 1982, Geyser eruptions: characteristics and mechanisms, with emphasis on 0ld Faithful Geyser, Yellowstone National Park, and Mount st. Helens, March-April 1980 (abs.): Abstract volume, Generation of Major Basalt Types, IAvCEI-IAGC Scientific Assembly, Reykjavik, Iceland, 1982, no. 102.

(P) Kieffer, S. W., 1984, Seismicity at old Faithful Geyser: an isolated source of geothermal noise and possible analogue of volcanic seismicity: Journal of Volcanology and Geothermal Research, v. 22. p. 59-95.

(P) Kieffer, S. W., 1985, Heat capacity and entropy: systematic relations to lattice vibrations, in Kieffer, S. W., and Navrotsky, A., eds., Microscopic to macroscopic: atomic environments to mineral thermodynamics: Reviews in Mineralogy, v. 14, p. 65-126.

(A) Kieffer, S. W., 1985, Estimated geometric mean spectral frequencies for a number of minerals (abs.): Eos, Transactions American Geophysical Union, v. 66, p. 400 .

(0) Kieffer, S. W., 1986, FORTRAN program for calculation of thermodynamic properties of minerals from vibrational spectra: U.S. Geological Survey Open-File Report 86-0475, $47 \mathrm{p}$.

(A) Kieffer, S. W., and Henley, R. W., 1986, Flow of $\mathrm{H}_{2} \mathrm{O}-\mathrm{CO}_{2}$ mixtures in geothermal wells: Prediction of calcite deposition (abs.): Geological Society of America Abstracts with Programs, v. 18, no. 6, P. 656 .

(P) Kieffer, S. W., and Navrotsky, A., 1985, Scientific perspective, in Kieffer, S. W., and Navrotsky, A., eds., Microscopic to macroscopic: atomic environments to mineral thermodynamics: Reviews in Minera $\log y$, v. 14, p. 1-8.

(P) Kieffer, S. W., and Navrotsky, A., eds., 1985, Microscopic to macroscopic: atomic environments to mineral thermodynamics: Reviews in Mineralogy, v. 14, 428p.

(A) Kieffer, S.W., and Westphal, J., 1985, Pressure and temperature measurements in Old Faithful Geyser (abs.): Eos, Transactions American Geophysical Union, v. 66, p. 1152.

(0) Kissling, E., Ellsworth, W. L., and Cockerham, R. S., 1984, Threedimensional structure of the Long Valley caldera, California, region by geotomography, in Hill D. P., Bailey, R. A., and Ryall, A. S., eds., Active tectonic and magmatic processes beneath Long Valley caldera, eastern California: U.S. Geological Survey Open-File Report 84-939, p. 188-220.

(A) Kissling, E., Hill, D. P., and Ellsworth, W. L., 1984, Imaging the Long Valley, California, crustal structure using seismic refraction and local earthquake data (abs.): Geological Society of America Abstracts with Programs, v. 16 , no. 6, p. 560.

(A) Kissling, E., Kradolfer, U., Hill, D. P., and Luetgert, J. H., 1984, Three dimensional central structure of Long Valley-Mono Lake region, eastern California, from seismic-refraction data (abs.): Eos, Transactions American Geophysical Union, v. 65, p. 1116.

(P) Knepper, D. H., Jr., 1983, Summary of some analys is techniques for linear features with examples from the Cascade Range: IEEE Digest, v. II, P. 6.1-6.5.

(0) Knepper, D. H., Jr., 1985, Analysis of linear features mapped from Landsat images of the Cascade Range, Washington, Oregon, and California: U.S. Geological Survey Open-File Report 85-150, $30 \mathrm{p}$. 
(A) Kohler, W. M., and Fuis, G. S., 1983, A time-term study of the Imperial Valley, California (abs.): Earthquake Notes, v. 54 , no. 1, p. 67.

(P) Kohler, W. M., and Fuis, G. S., 1986, Travel-time, time-term, and basement depth maps for the Imperial Valley region, California, from explosions: Bulletin of the Seismological Society of America, v. 76, p. 1289-1303.

(P) Kohler, W. H., Healy, J. H., and Wegener, S. S., 1982, Upper crustal structure of the Mt. Hood, Oregon, region as revealed by time term analysis: Journal of Geophysical Research, v. 87, p. 339-355.

(P) Kraemer, T. F., and Kharaka, Y. K., 1986, Urnanium geochemistry in geopressured-geothermal aquifers of the U.S. Gulf Coast: Geochimica et Cosmochimica Acta, v. 50, p. 1233-1238.

(A) Kuntz, M. A., Champion, D. E., Spiker, E. C., Miesch, A. T., and Lefebvre, R. H., 1982, Time, volume, and composition history of the Craters of the Moon lava field, Idaho (abs.): Geological Society of America Abstracts with Programs, v. 14 , no. 6, p. 318.

(P) Lachenbruch, A. H., 1986, Reply to Comments on "Models of an extending lithosphere and heat flow in the Basin and Range Province": Journal of Geophysical Research, v. 91, p. 7565-7569.

(P) Lachenbruch, A. H., Sass, J. H., and Galanis, S. P., Jr.,1985, Heat flow in southernmost California and the origin of the Salton Trough: Journal of Geophysical Research, v. 90, p. 6709-6736.

(A) Lachenbruch, A. H., Sass, J. H., Galanis, S. P., Jr., and Marshal1, B. V., 1983, Heat flow, crustal extension, and sedimentation in the Salton Trough (abs.): Eos, Transactions American Geophysical Union, v. 64, p. 836 .

(A) Lachenbruch, A. H., Sass, J. H., Galanis, S. P., Jr., and Marshall, B. V., 1983, Heat flow and crustal extension in the Salton Trough (abs.): International Union of Geodesy and Geophysics, XVIII Federal Assembly, Hamburg, Germany, Program and abstracts, v. 1, p. 504.

(A) Leaver, D. L., Mooney, W. D., and Kohler, W. M., 1982, A refraction study of the Oregon Cascades (abs.): Earthquake Notes, v. 53, no. 1, p. 23.

(P) Leaver, D. S., Mooney, W. D., and Kohler, W. M., 1984, A seismic refraction study of the Oregon Cascades: Journal of Geophysical Research, v. 89, p. 3121-3134.

(P) Lehman, J. A., Smith, R. B., Schilly, M. M., and Braile, L. W., 1982, Upper crustal structure of the Yellowstone caldera from seismic delay time analyses and gravity correlations: Journal of Geophysical Research, v. 87, p. 2713-2730.

(P) Lico, M. S., and Kharaka, Y. K., 1985, Subsurface pressure and temperature distributions in Sacramento basin, California: Selected papers of Pacific Section, American Association of Petroleum Geologists Meeting, 1983, Sacramento, v. 1, p. 57-77.

(P) Lico, M. S., and Kharaka, Y. K., Carothers, W. W., and Wright, V. A., 1982, Methods for collection and analysis of geopressured geothermal and oil field waters: U.S. Geological Survey Water-Supply Paper $2194,21 \mathrm{p}$.

(P) Lipman, P. W., 1983, Tectonic setting of the mid- to Late Tertiary in the Rocky Mountain region--a review, in The Genesis of Rocky Mountain Ore Deposits: Changes with Time and Tectonics: Proceedings of the Denver Region Exploration Geologists Society Symposium, p. 125-131.

(P) Lipman, P. W., 1983, The Miocene Questa caldera, northern New Mexico: relation to batholith emplacement and associated molybdenum mineralization in The Genesis of Rocky Mountain Ore Deposits: Changes with Time and Tectonics: Proceedings of the Denver Region Exploration Geologists Society Symposium, p. 133-149. 
(P) Lipman, P. W., 1984, Ash-flow calderas in western North America, in Growth and evolution of volcanic edifices: Geological Association of Canada Short Course notes, v. 4, p. 124-161.

(P) Lipman, P. W., 1984, Evolution of the Oligocene-Miocene Questa magmatic system, Rio Grande rift, northern New Mexico, in Dungan, M. A., Grove, T. L., and Hildreth, Wes, eds., Proceedings of the Conference on Open Magmatic Systems, Ranchos de Taos, New Mexico: Southern Methodist University, p. 99-101.

(0) Lipman, P.W., 1984, structure of the Tertiary Questa caldera, New Mexico--An eroded analog for current activity at Long Valley, in Hill D. P., Bailey, R. A., and Ryall, A. S., eds., Active tectonic and magmatic processes beneath Long Valley caldera, eastern California: U.S. Geological Survey Open-File Report 84-939, p. 851-885.

(P) Lipman, P.W., 1984, The roots of ash flow calderas in western North America: windows into the tops of granitic batholiths: Journal of Geophysical Research, v. 89, p. 8801-8841.

(A) Lipman, P. W., 1986, Emplacement of large ash-flow sheets and relation to caldera collapse (abs.): International Volcanological Congress, New Zealand, p. 58.

(A) Lipman, P. W., and Banks, N. C., 1984, A'a flow dynamics, 1984 Mauna Loa eruption (abs.): Eos, Transactions American Geophysical Union, v. 65, p. 1138 .

(P) Lipman, P. W. , Banks, N. G., and Rhodes, J. M., 1985, Degassing-induced crystallization of basaltic magma and effects on lava rheology: Nature, v. 317, p. 604-607.

(P) Lipman, P. W., Mehnert, H. H., and Naeser, C. W., 1986, Evolution of the Latir volcanic field, northern New Mexico, and its relation to the Rio Grande Rift, as indicated by potassium-argon and fission track dating: Journal of Geophysical Research, v. 91, p. 6329-6345.

(P) Lipman, P.W., and Reed, J. C., Jr., 1984, Second-day road log: From Taos to Hondo Canyon, Questa, Red River, and back to Taos: New Mexico Geological Society Guidebook, p. 321-347.

(P) Lipman, P. W., Self, S., and Heiken G., 1984, Introduction to Calderas Special Issue: Journal of Geophysical Research, v. 89, p. 8219-8221.

(P) Lipman, P.W., Self, S., and Heiken G., 1984, eds., Special issue on calderas and associated igneous rocks: Journal of Geophysical Research, v. 89, p. 8219-8841.

(A) Lockwood, J. P., Decker, R. W., Jackson, D. B., Koyanagi, R. Y., Okamura, A. T., and Johnson, D. J., 1984, The 1984 eruption of Mauna Loa volcano, Hawaii (abs.): Eos, Transactions American Geophysical Union, v. 65, p. 1137 .

(A) Lockwood, J. P., and Lipman, P. W., 1985, Holocene eruptive history of Mauna Loa volcano, Hawaii (abs.): Eos, Transactions American Geophysical Union, v. 66, p. 1132.

(P) Lowell, R. P., and Hernandez, H., 1982, Finite amplitude convection in a porous container with fault-like geometry: effect on initial boundary conditions: International Journal of Heat and Mass Transfer, v. 25, no. 5, p. 631-641.

(P) Ludwin, R. S., Cagnetti, V., and Bufe, C. G., 1982, Comparison of seismicity in The Geysers geothermal area with the surrounding region: Seismological Society of America Bulletin, v. 72, P. 863-871.

(P) Luedke, R. G., and Smith, R. L., 1982, Map showing distribution, composition, and age of Late Cenozoic volcanic centers in oregon and Washington: U.S. Geological Survey Miscellaneous Investigations Series Map I-1091-D, scale $1: 1,000,000$. 
(P) Luedke, R. G., and Smith, R. L., 1983, Map showing distribution, composition, and age of Late Cenozoic volcanic centers in Idaho, western Montana, western South Dakota, northwestern Wyoming: U.S. Geological Survey Miscellaneous Investigations Series Map I-1091-E, scale $1: 1,000,000$.

(P) Luedke, R. G., and Smith, R. L., 1984, Map showing distribution, composition, and age of Late Cenozoic volcanic centers in the western conterminous United States: U.S. Geological Survey Miscellaneous Investigations Series Map I-1523, scale 1:2,500,000.

(P) Luedke, R. G., Smith, R. L., and Russe11-Robinson, S. L., 1983, Map showing distribution, composition, and age of Late Cenozoic volcanoes and volcanic rocks of the Cascade Range and vicinity, northwestern United States: U.S. Geological Survey Miscellaneous Investigations Series Map I-1507, scale 1:500,000.

(A) Lysne, P. C., Eichelberger, J. C., Younker, L.W., and Miller, C. D., 1985, Implementation of the Inyo drilling program (abs.): Eos, Transactions American Geophysical Union, v. 66, p. 384.

(P) Mabey, D. R., 1983, Geothermal resources of southern Idaho: U.S. Geological Survey Circular 866, 24p.

(P) MacLeod, N. S., and Samme1, E. A., 1982, Newberry Volcano, Oregon-A Cascade Range geothermal prospect: California Geology, v. 35, no. 11, p. 235-244. Oregon Geology, v. 44, no. 11, p. 123-131.

(A) MacLeod, N. S., and Sherrod, D. R., 1985, The magmatic system of Newberry Volcano, Oregon, in Guffanti, M., and Muffler, L. J. P, eds., 1985, Proceedings of the workshop on geothermal resources of the Cascade Range: U.S. Geological Survey Open-File Report 85-521, p. 40-41.

(A) MacLeod, N. S., and Swanson, D. A., 1985, Volcanism in the Cascade Range, in Guffanti, M., and Muffler, L. J. P, eds., 1985, Proceedings of the workshop on geothermal resources of the Cascade Range: U.S. Geological Survey Open-File Report 85-521, p. 18-23.

(P) Mahood, G. A., and Hildreth, W., 1983 , Nested calderas and trapdoor uplift at Pantelleria, Strait of Sicily: Geology, v. 11, p. 722-726.

(P) Mahood, G., and Hildreth, W., 1983, Large partition coefficients for trace elements in high-silica rhyolites: Geochimica et Cosmochimica Acta, v. 47, p. 11-30.

(P) Mahood, G. A., and Hildreth, W., 1986, Geology of the peralkaline volcano at Pantelleria, Strait of Sicily: Bulletin of Volcanology, v. 48, p. 143-172.

(P) Mahood, G. A., Truesdell, A. H., and Templos, L. A., 1983, A reconnaissance geochemical study of La Primavera geothermal area, Jalisco, Mexico: Journal of Volcanology and Geothermal Research, v. 16, p. $247-261$.

(P) Makdisi, R. S., Truesdel1, A. H., Thompson, J. M., Coplen, T. B., and Sanchez, J., 1982, Geochemical evolution of Mexicali valley groundwaters: Proceedings of 4th Symposium on the Cerro Prieto Geothermal Field, Baja California, Mexico, Guadalajara, Mexico, August 10-12, 1982, p. 551-562.

(0) Mangan, M. T., and Helz, R. T., 1986, The distribution of vesicles and olivine phenocrysts in samples from drill hole KI 79-3, Kilaeua Iki lava lake, Hawaii: U.S. Geological Survey Open-File Report 86-0424, $43 \mathrm{p}$.

(A) Mariner, R. H., 1985, Geochemical features of Cascades hydrothermal systems, in Guffanti, M., and Muffler, L. J. P, eds., 1985, Proceedings of the workshop on geothermal resources of the Cascade Range: U.S. Geological Survey Open-File Report 85-521, p. 59-62. 
(P) Mariner, R. H., Brook, C. A., Reed, M. J., Bliss, J. D., Rapport, A. L., and Lieb, R. J., 1983, Low-temperature geothermal resources in the western United States, in Reed, M. A., ed., Assessment of low-temperature geothermal resources of the United States--1982: U.S. Geological Survey Circular 892, p. 31-50.

(P) Mariner, R. H., Presser, T. S., and Evans, W. C., 1983, Geochemistry of active geothermal systems in the northern Basin and Range Province: in The role of heat in the development of energy and mineral resources in the northern Basin and Range province, Geothermal Resources Council, Special Report no. 13, p. 95-119.

(0) Mase, C. W., Sass, J. H., Lachenbruch, A. H., and Munroe, R. J., 1982, Preliminary heat-flow investigations of the California Cascades: U.S. Geological Survey Open-File report 82-0150, 242 p.

(P) Mazor, E., and Thompson, J. M., 1982, Evolution of geothermal fluids deduced from chemistry plots: Yellowstone National Park (USA): Journal Volcanolology and Geothermal Reseach, v. 12, p. 351-360.

(P) Mazor, E., and Truesdell, A. H., 1984, Dynamics of a geothermal field traced by noble gases: Cerro Prieto, Mexico: Geothermics, v. 13, p. 91-102.

(A) McLaughlin, R. J., Moore, D. E., Sorg, D. H., and McKee, E. H., 1983, Multiple episodes of hydrothermal circulation, thermal metamorphism, and magma injection beneath the Geysers steam field, California (abs.): Geological Society of America Abstracts with Programs, v. 15 , no. 5, p. 417 .

(P) McLaughlin, R. J., and Ohlin, H. N., 1984, Tectonostratigraphic framework of the Geysers-Clear Lake region, California, in Blake, M. C.. Jr., ed., Franciscan Geology of northern California: Society of Economic Paleontologists and Mineralogists, Pacific Section, v. 43, p. 221-254.

(A) McLaughlin, R. J., Ohlin, H. N., and Blome, C. D., 1983, Tectonostratigraphic framework of the Franciscan assemblage and lower part of the Great Valley sequence in the Geysers-Clear Lake Region, California (abs.): Eos, Transactions American Geophysical Union, v. 64, p. 868 .

(0) McLaughlin, R. J., Ohlin, H. N., Thormahlen, D. J., Jones, D. L., Miller, J.W., and Blome, C. D., 1985, Geologic map and structure sections of the Little Indian Valley-Wilbur Springs geothermal area, northern Coast Ranges, California: U.S. Geological Survey Open-File Report 85-285, 2 plate, 24 p.

(P) McMechan, G. A., Clayton, R. W., and Mooney, W. D., 1982, Application of wave field continuation to the inversion of refraction data: Journal of Geophysical Research, v. 87, p. 927-935.

(P) McMechan, G. A., Luetgert, J. H., and Mooney, W. D., 1985, Imaging of earthquake sources in Long Valley caldera, California: Bulletin of the Seismological Society of America, v. 75, p. 1005-1020.

(P) Mankinen, E. A., Grommé, C. S., Dalrymple, G. B., Lanphere, M. A., and Bailey, R. A., 1986, Plaeomagnetism and $\mathrm{K}-\mathrm{Ar}$ ages of volcanic rocks from Long Valley, California: Journal of Geophysical Research, v. $91, p .633-652$.

(0) Meador, P. J., and Hil1, D. P., 1983, Data report for the August 1982 seismic-refraction experiment in the Mono Craters-Long Valley region, California: U.S. Geological Survey Open-File Report 83-7,08, 55p.

(P) Michaelson, C. A., and Weaver, C. S., 1986, Upper mantle structure from teleseismic $P$ wave arrivals in Washington and northern Oregon: Journal of Geophysical Research, v. 91, p. 2077-2094. 
(A) Miller, C. D., Eichelberger, J. C., and Lysne, P. C., 1985, Scientific drilling at Inyo Domes, California: Geologic and background and scientific objectives (abs.): Eos, Transactions American Geophysical Union, v. 66, p. 384 .

(A) Miller, T. P., and Smith, R. L., 1983, Calderas of the eastern Aleutian arc (abs.): EOS Transactions American Geophysical Union, v. 64, p. 877 .

(P) Moench, A. F., 1982, Geothermal well test analysis in horizontally stratified formations including well-bore storage and skin effects: International Conference on geothermal energy, Florence, Italy, BHRA Fluid Enginering, May 11-14, 1982, p. 267-279.

(P) Moench, A. F., 1983, Well-test analysis in naturally fissured, geothermal reservoirs with fracture skins: Proceedings Ninth Workshop on Geothermal Reservoir Engineering, Stanford, CA, SGP-TR-74, p. $175-180$.

(P) Moench, A. F., 1984, Double-porosity models for a fissured groundwater reservoir with fracture skin: Water Resources Research, v. 20, p. 831-846.

(P) Moench, A. F., 1985, Transient flow to a large-diameter well in an aquifer with storative semiconfining layers: Water Resources Research, v. 21, p. 1121-1131.

(P) Moench, A. F., and Hsieh, P. A., 1985, Slug testing in wells with finite-thickness skin: Proceedings Tenth Workshop on Geothermal Reservoir Engineering, stanford, CA, SGP-TR-84, p. 169-175.

(P) Moench, A. F., Hsieh, P. A., Faust, C. R., and Mercer, J. W., 1985, Evaluation of slug tests in wells containing a finite-thickness skin: Water Resources Research, v. 21, p. 1459-1462.

(P) Moench, A. F., and Ogata, Akio, 1984, Analysis of constant discharge wells by numerical inversion of Laplace transform solutions: Water Resources Monographs, v. 9, p. 146-170.

(A) Moore, J. G., and Clague, D. A., 1982, Volatile content of Loihi lavas, Hawai (abs.): Abstract volume, Generation of major basalt types, IAVCEI-IAGC Scientific Assembly, Reykjavik, Iceland, 1982, no. 100.

(P) Moore, J. G., Jakobsson, S. P., and Norrman, J. 0., 1986, Investigation of Surtsey volcano: Bos, Transactions American Geophysical Union, v. $67, \mathrm{p} .74$.

(P) Moore, R. B., 1983, Distribution of differentiated tholeitic basalts on the lower East Rift Zone of Kilauea Volcano, Hawaii: a possible guide to geothermal exploration: Geology, v. 11, p. 136-140.

(0) Moore, R. B., 1986, Preliminary geologic map of the Pahoa South quadrangle, eastern Hawaii: U.S. Geological Survey Open-File Report $85-0715,2$ sheets, scale $1: 24,000$.

(0) Moore, R. B., 1986, Preliminary geologic map of Agua de Pau volcano, São Miguel, Azores: U.S. Geological Survey Open-Pile Report 86-0192, 1 sheet, scale $1: 18,000$.

(0) Moore, R. B., Trusdell, F. A., Clague, D. A., and Bohrson, W. A., 1986, Preliminary geologic map of the Hualalai quadrangle, Hawaii: U.S. Geological survey Open-File Report 86-0270, 2 sheets, scale 1:24,000.

(P) Morgan, P., and Sass, J. H., 1984, Thermal regime of the continental lithosphere: Journal of Geodynamics, v. 1, p. 143-166.

(A) Muffler, L. J. P., 1983, Scientific drilling to study the roots of active hydrothermal systems related to young magmatic intrusions (abs.): Geological Society of America Abstracts with Programs, v. 15, no. 5, p. 434 .

(P) Muffler, L. J. P., 1985, Geothermal energy and geothermal resources in hydrothermal convection systems, in Perrine, R. L., ed., Energy; for ourselves and our posterity, Englewood Cliffs, NJ, Prentice-Hall, p. 188-207. 
(A) Muffler, L. J. P., 1985, Undiscovered geothermal resources of the United States, in Guffanti, M., and Muffler, L. J. P, eds., 1985, Proceedings of the workshop on geothermal resources of the Cascade Range: U.S. Geological Survey Open-File Report 85-521, p. 7-9.

(A) Muffler, L. J. P., 1986, Volcanic processes influencing development of geothermal resources (abs.): American Association of Petroleum Geologists Bulletin, v. 70, no. 7, p. 931-932.

(P) Muffler, L. J. P., Bacon, C. R., and Duffield, W. A., 1982, Geothermal systems of the Cascade Range: Proceedings of Pacific Geothermal Conference 1982 incorporating the 4 th New Zealand Geothermal Workshop, p. 337-343.

(O) Muffler, L. J. P., Clynne, M. A., and Cook, A. L., 1982, Mineral and geothermal resources of the wild Cattle Mountain and Heart Lake Roadless Areas, Tehama, Shasta, and Plumas Counties, California: U.S. Geological Survey Open-File Report 82-846, 25 p.

(P) Muffler, L. J. P., Jordan, R., Cook, A. L., 1983, Thermal features and topography of Bumpass Hell and Devils Kitchen, Lassen Volcanic National Park, California: U.S. Geological Survey Miscellaneous Field Studies Map MF-1484, scale 1:2,000.

(A) Muffler, L. J. P., and Nathenson, M., 1986, The U.S. Geological Survey Geothermal Research Program (abs.), in USGS Research on Energy Resources - 1986, Program and Abstracts: U.S. Geological Survey Circular 974, p. 79-80.

(P) Muffler, L. J. P., Nehring, N. L., Truesdell, A. H., Janik, C. J., Clynne, M. A., and Thompson, J. M., 1982, The Lassen geothermal system: Proceedings of the Pacific Geothermal Conference 1982 incorporating the 4th New Zealand Geothermal Workshop, p. 349-356.

(P) Muffler, L. J. P., White, D. E., Beeson, M. H., and Truesdell, A. H., 1982, Geologic map of Upper Geyser Basin, Yellowstone National Park, Wyoming: U.S. Geological Survey Miscellaneous Investigations Series, Map I-1371, scale $1: 4,800$..

(P) Muffler, L. J. P., White, D. B., Truesdell, A. H., and Fournier, R. 0., 1982, Geologic map of Lower Geyser Basin, Yellowstone National Park, Wyoming: U.S. Geological Survey Miscellaneous Investigations series, Map I-1373, scale $1: 24,000$.

(0) Murakami, Y., Zerilli, A., and Bisdorf, R. J., 1986, A computer program for the automatic inversion of Schlumberger soundings using multi-layer interpretation followed by Dar Zarrouk reduction: U.S. Geological Survey Open-File Report 86-288, 36 p.

(P) Nathenson, M., 1983, High-temperature geothermal resources in hydrothermal convection systems in the United States: Proceedings of the Seventh Annual Geothermal Conference and Workshop, Electric Power Research Institute, EPRI AP-3271, p. 7-1 to 7-2.

(P) Nathenson, К., 1983, The 1982 International Conference on geothermal energy, Florence, Italy: Geothermal Resources Council Bulletin, v. 12 , no. 2 , p. 9-11.

(P) Nathenson, K., 1984, Assessment of high-temperature geothermal resources in hydrothermal convection systems in the United States:

Proceedings, 19th Intersociety Energy Conversion Engineering Conference, San Francisco, v. 3, p. 1295-1299.

(A) Nathenson, К., 1984, Geothermal resource assessment in the U.S. Geological Survey (abs.): The 3rd New Energy Industrial Symposium, New Energy Foundation, Tokyo, Japan, p. 78.

(P) Nathenson, M., and Guffanti, M., 1982, Preliminary geothermal gradient map of the conterminous United States: International Conference on geothermal energy, Florence, Italy, BHRA Fluid Enginering, May 11-14, 1982 p. 79-84. 
(P) Nathenson, M., Guffanti, M., Sass, J. H., and Munroe, R. J., 1983, Regional heat flow and temperature gradients, in Reed, M. J., ed., Assessment of low-temperature geothermal resources of the United States: U.S. Geological Survey Circular 892, p. 9-16.

(P) Nathenson, M., Nehring, N. L., Crosthwaite, E. G., Harmon, R. S., Janik, C. J., and Borthwick, J., 1982, Chemical and light-stable isotope characteristics of waters from the Raft River geothermal area and environs, Cassia County, Idaho, Box Elder County, Utah: Geothermics, v. 11, p. 215-237.

(P) Nehring, N. L., and D'Amore, F., 1984, Gas chemistry and thermometry of the Cerro Prieto, Mexico, geothermal field: Geothermics, v. 13, p. 75-89.

(P) Nehring, H. L., DesMarais, D. J., and Truesde11, A. H., 1982, Thermal decomposition of hydrocarbons in the Cerro Prieto, Mexico, geothermal reservoir: Geothermal Resource Council Transactions, v. 6, p. 305-307.

(P) Nehring, N. L., and Valette-Silver, J. N., 1982, Gas reactions in the Cerro Prieto Reservoir: Proceedings of 4 th Symposium on the Cerro Prieto Geothermal Field, Baja California, Mexico, Guadalajara, Mexico, August $10-12,1982$, p. 525-530.

(P) Newman, G. A., Hohmann, G. W., and Anderson, W. L., 1986, Transient electromagnetic response of a three-dimensional body in a layered earth: Geophysics, v. 51, p. 1608-1627.

(P) Normark, W. R., Clague, D. A., and Moore, J. G., 1982, Hawai i: the next island: Natural History Magazine, v. 9, no. 12, p. 68-71.

(P) Norton, D. R., and Friedman, I., 1985, Chloride flux out of Yellowstone Park: Journal of Volcanology and Geothermal Research, v. 26, p. 231-250.

(A) Novak, S. W., and Bacon, C. R., 1983, Magma mixing and fractionation recorded in Pliocene volcanic rocks of the Coso Range, California (abs.): Geological Society of America Abstracts with Programs, v. 15 , no. 5, p. 432 .

(P) Novak, S. W., and Bacon, C. R., 1986, Pliocene volcanic rocks of the Coso Range, Inyo County, California: U.S. Geological Survey Professional Paper 1383, $44 \mathrm{P}$.

(A) Olhoeft, G. R., 1983, Electrical properties of water-and steam-saturated zeolite (abs.): Eos, Transactions American Geophysical Union, v. 64, p. 692-693.

(A) Olhoeft, G. R., 1983, Estimating geological noise from physical property databases (abs.): International Union of Geodesy and Geophysics, XVIII Federal Assembly, Hamburg, Germany, Program and abstracts.

(A) Olhoeft, G. R., 1983, Geologic noise: the limit of accuracy and resolution (abs.): Third Biennial Conference of the ASEG, Brisbane, October 31-November 3.

(P) Olmsted, F. H., and Ingebritsen, S. E., 1986, Shallow subsurface temperature surveys in the Basin and Range Province - II. Ground temperatures in the Upsal Hogback geothermal area, west-central Nevada, U.S.A.: Geothermics, v. 15, p. 267-275.

(P) Olmsted, F. H., Welch, A. H., and Ingebritsen, S. E., 1986, Shallow subsurface temperature surveys in the Basin and Range Province, U.S.A. - I. Review and evaluation: Geothermics, v. 15, p. 251-265.

(P) Olmsted, F. H., Welch, A. H., Van Denburgh, A. S., and Ingebritsen, S. E., 1984, Geohydrology, aqueous geochemistry, and thermal regime of the Soda Lakes and Upsal Hogback geothermal systems, Churchill County, Nevada: U.S. Geological Survey Water Resources Investigations Report 84-4054, 166 P. 
(P) Oppenheimer, D. H., 1985, Induced seismicity mechanism at The Geysers, California: Geothermal Resources Council Transactions, v. 9, part II, P. 41-44.

(A) Oppenheimer, D. H., 1985, Induced seismicity at The Geysers (abs.): Earthquake Notes, v. 56, P. 17.

(P) Oppenheimer, D. H., 1986, Extensional tectonics at The Geysers geothermal area, California: Journal of Geophysical Research, v. 91, p. 11,463-11,476.

(A) Oppenheimer, D. H., 1986, Induced seismicity and the state of stress at The Geysers geothermal area, California (abs.), in USGS Research on Energy Resources - 1986, Program and Abstracts: U.S. Geological Survey Circular 974, p. 47.

(A) Oppenheimer, D., and Eberhart-Phillips, D., 1983, Induced seismicity at The Geysers, California (abs.): Geophysics, v. 48. p. 478-479 (Extended version printed in the Technical Program of the 52nd Annual International Meeting of the Society of Exploration Geophysicists, 1982, Dallas, TX).

(P) Paillet, F. L., and Keys, W. S., 1984, Applications of borehole geophysics in characterizing the hydrology of fractured rocks: National Water Well Association, Symposium on Surface and Borehole Geophysical Methods in Ground Water Investigations, San Antonio, TX, P. 743-761.

(A) Paillet, F. L., Morin, R. H., and Keys, W. S., 1986, Borehole geophysical applications in the characterization of geothermal energy resources (abs.), in USGS Research on Energy Resources - 1986, Program and Abstracts: U.S. Geological Survey Circular 974, p. 51-52.

(P) Pallister, J. S., 1984, Open-system magmatism: Examples from the Oman ophiolite and Red Sea Rift, in Dungan, M. A., Grove, T. L., and Hildreth, Wes, eds., Proceedings of the Conference on Open Magmatic Systems, Ranchos de Taos, New Mexico: Southern Methodist University, p. 129-130.

(P) Pankratz, L. W., and Ackermann, H. D., 1982, Structure along the northwest edge of the Sanke River Plain interpreted from seismic refraction: Journal of Geophysical Research, v. 87, p. 2676-2682.

(P) Pelton, J. R., and Smith, R. B., 1982, Contemporary vertical surface displacements in Yellowstone National Park: Journal of Geophysical Research, v. 87, p. 2745-2761.

(P) Pitt, A. M., and Hutchinson, R. A., 1982, Hydrothermal changes related to earthquake activity at Mud Volcano, Yellowstone National Park, Wyoming: Journal of Geophysical Research, v. 87, p. 2762-2766.

(P) Pollard, D. D., Delaney, P. T., Duffield, W. A., Endo, E. T., and Okamura, A. T., 1983, Surface deformation in volcanic rift zones: Tectonophysics, v. 94, p. 541-584.

(0) Pollard, D. D., Fink, J. H., and Delaney, P. T., 1984, Igneous dikes at Long Valley, CA: emplacement mechanisms and associated geologic structures, in Hill D. P., Bailey, R. A., and Ryall, A. S., eds., Active tectonic and magmatic processes beneath Long Valley caldera, eastern California: U.S. Geological Survey Open-File Report 84-939, p. 131-146.

(P) Pollard, D. D., Segall, P., and Delaney, P. T., 1982, Formation and interpretation of dilatent echelon cracks: Geological society of America Bulletin, v. 93, p. 1291-1303.

(P) Pratt, R., Kassoy, D. R., and Gary, J., 1983, Heat and mass transfer in a fault zone-controlled geothermal reservoir: numerical results: Journal of Geophysical Research, v. 88, p. 3458-3466.

(P) Priestley, K. F., and Brune, J. N., 1982, Shear wave structure of the southern volcanic plateau of oregon and Idaho and the northern Great Basin of Nevada from surface wave dispersion: Journal of Geophysical Research, v. 87, p. 2671-2675. 
(0) Rapport, A. L., 1982, FORTRAN program to compute chemical geothermometers for geothermal fluids: U.S. Geological Survey Open-File Report $82-308,25 \mathrm{p}$.

(P) Reed, M. J., 1982, Data for geothermal wells in The Geysers-Clear Lake Area of California as of Nov. 80: Geothermal Resources Council Special Report No. $11,43 \mathrm{p}$.

(0) Reed, M. J., 1982, Latitude, longitude, and California Lambert coordinates for 229 wells in The Geysers geothermal field, California: U.S. Geological Survey Open-File report $82-0410,11 \mathrm{p}$.

(P) Reed, H. J., ed., 1983, Assessment of low-temperature geothermal resources of the United States: U.S. Geological Survey Circular 892, 73 p.

(P) Reed, M. J., and Bliss, J. D., 1983, Geothermal resources and their use for small-scale development, in Meyer, R. F., and olson, J. C., eds., Future small energy resources: United Nations Institute for Training and Research, Proceedings, 1982, Conference on Small Energy Sources, p. 289-296.

(A) Rhodes, J. M., Sparks, J. W., Lockwood, J. P., and Lipman, P. W., 1983,. Compositional constraints on the structure of Mauna Loa volcano (abs.): Eos, Transactions American Geophysical Union, v. 64, p. 900 .

(P) Riney, T. D., Garg, S. K., and Wallace, R. H., Jr., 1985, Effect of shale-water recharge on brine and gas recovery from geopressured reservoirs, in Dorfman, M. H., and Morton, R. A., eds., Geopressured-geothermal energy: New York, Pergamon Press, p. 193-202.

(0) Rinney, T. D., Pritchett, J. W., and Rice, L. F., 1982, Integrated model of the shallow and deep hydrothermal systems in the East Mesa area, Imperial Valley, California: U.S. Geological Survey Open-File report $82-980,118 \mathrm{p}$.

(P) Rodrigues Da Silva, A. M. , Duffield, W. A., and Muffler, L. J. P., 1985, Geothermal studies of Agua de Pau volcano, Sao Miguel, Azores: Geothermal Resources Council Transactions, v. 9, part II, p. 395-399.

(P) Rundle, J. B., Elbring, G. J, Striker, R. P., Finger, J. T., Carson, C. C., Walck, M. C., Ellsworth, W. L., Hill, D. P., Malin, P., Tono, E., Robertson, M., Kuhlman, S., McEvilly, T., Clymer, R., Smithson, S. B., Deemer, S., Johnson, R., Henyey, T., Hauksson, E., Leary, P., McCraney, J., and Kissling, E., 1985, Seismic imaging in Long Valley, California, by surface and borehole techniques: An investigation of active tectonics: Eos, Transactions American Geophysical Union, v.66, p. 194-201.

(A) Rundle, J. B., Ellsworth, W. R., Malin, P., McEvilly, T., Smithson, S. B., and Henyey, T., 1985, Seismic imaging in Long Valley, California (abs.): Eos, Transactions American Geophysical Union, v. 66, p. 301.

(P) Rush, F. E., 1983, Reconnaisance of the hydrothermal resources of Utah: U.S. Geological Survey Professional Paper 1044-H, 49p.

(A) Ryan, M. P., 1985, The contractancy mechanics of magma reservoir and rift system evolution (abs.): Eos, Transactions American Geophysical Union, v. 66, p. 854 .

(P) Ryan, M. P., Blevins, J. Y. K., Okamura, A. T., and Koyanagi, R. Y., 1983, Magma reservoir subsidence mechanics: theoretical summary and application to Kilauea Volcano, Hawai: Journal of Geophysical Research, v. 88, p. 4147-4181.

(A) Salinas, J., White, L. D., and Thompson, J. M., 1984, Studies on chemical, isotopic, and limnological parameters of Crater Lake, Oregon (abs.): Eos, Transactions American Geophysical Union, v. 65, p. 885.

(P) Samme1, E. A., 1983, The shallow hydrothermal system at Newberry Volcano, Oregon: a conceptual model: Geothermal Resources Council Transactions, v. 7, p. 325-330. 
(P) Samme1, E. A., ed., 1984, Analysis and interpretation of data obtained in tests of the geothermal aquifer at Klamath Falls, Oregon: U.S. Geological Survey Water Resources Investigations Report 84-4216, $169 \mathrm{p}$.

(0) Sammel, E. A., and Craig, R. W., 1982, The geothermal hydrology of Warner Valley, Oregon: A reconnaissance study: U.S. Geological Survey Professional Paper 1044-I, $47 \mathrm{p}$.

(P) Sammel, E. A., and Craig, R. W., 1983, Hydrology of the Newberry Volcano caldera, Oregron: U.S. Geological Survey Water Resources Investigations Report 83-4091, $52 \mathrm{p}$.

(P) Sass, J. H., 1982, Review of the book "Geothermal Systems: Principles and Case Histories" by L. Rybach and L. J. P. Muffler (eds.): Journal of Volcanology and Geothermal Research, v. 14, p. 399-401.

(P) Sass, J.H., and Elders, W. A., 1986, Salton Sea scientific drilling project: Scientific program: Geothermal Resources Council Transactions, v. 10 , p. 473-478.

(0) Sass, J. H., Galanis, S. P., Jr., Lachenbruch, A. H., Marshal1, B. V., and Munroe, R. J., 1984, Temperature, thermal conductivity, heat flow, and radiogenic heat production from unconsolidated sediments of the Imperial Valley, California: U.S. Geological Survey Open-File Report $84-490,38 \mathrm{p}$.

(0) Sass, J. H., Galanis, S. P., Jr., and Munroe, R. J., 1982, Measurement of heat flow by a downhole probe technique in the San Joaquin Valley, California: U.S. Geological Survey Open-File Report 82-819, 27 p.

(A) Sass, J. H., Hendricks, J. D., Priest, S. S., and Robison, L. C., 1986, The Salton Sea scientific drilling program - A progress report (abs.), in USGS Research on Energy Resources - 1986, Program and Abstracts: U.S. Geological Survey Circular 974, p. 60-61.

(0) Sass, J. H., Kennelly, J. P., Jr., Smith, E. P., and Wendt, W. E., 1984, Laboratory line-source methods for the measurement of thermal conductivity of rocks near room temperature: U.S. Geological survey Open-File Report 84-91, 21 p.

(P) Sass, J. H., Lawver, L. A., and Munroe, R. J., 1985, A heat-flow reconnaissance of southeastern Alaska: Canadian Journal of Earth Sciences, v. 22, p. 416-421.

(0) Sass, J. H., Stone, C., and Bills, D. J., 1982, Shallow subsurface temperatures and some estimates of heat flow from the Colorado Plateau of northeastern Arizona: U.S. Geological Survey Open-File Report 82-994, 112 p.

(P) Sass, J.H., Stone, C., and Munroe, R. J., 1984, Thermal conductivity determinations on solid rock--A comparison between a steady-state divided-bar apparatus and a commercial transient line-source device: Journal of Volcanology and Geothermal Research, v. 20, p. 145-153.

(P) Savage, J. C., and Cockerham, R. S., 1984, Earthquake swarm in Long Valley caldera, California, January 1983: Evidence for dike inflation: Journal of Geophysical Research, v. 89, p. 8315-8324.

(A) Sawyer, D., and Lipman, P. W., 1984, Petrology and geochemistry of coeval silicic volcanic and plutonic rocks associated with the Cretaceous porphyry copper deposit at silver Bell, Arizona (abs.): Eos, Transactions American Geophysical Union, v. 65, p. 1127.

(P) Schilly, M. M., Smith, R. B., Braile, L. W., Ansorge, J., 1982, The 1978 Yellowstone-eastern Snake River Plain seismic profiling experiment: data and upper crustal structure of the Yellowstone Region: Journal of Geophysical Research, v. 87, p. 2692-2704.

(A) Scott, W. E., and Gardner, C. A., 1985, Late Pleistocene - early Holocene development of the Bachelor Butte volcanic zone, Cascade Range, Oregon (abs.): Eos, Transactions American Geophysical Union, v. 66, p. 1141 . 
(0) Shaw, H. R., 1984, A note on links between magma-tectonic rate balances, plutonism and volcanism, in Hill D. P., Bailey, R. A., and Ryall, A. S., eds., Active tectonic and magmatic processes beneath Long Valley caldera, eastern California: U.S. Geological Survey Open-File Report 84-939, p. 886-942.

(P) Shaw, H. R., 1985, Links between magma-tectonic rate balances, plutonism and volcanism: Journal of Geophysical Research, v. 90, p. 11,27511,288 .

(P) Sheppard, D. S., and Truesde11, A. H., 1985, A GC-system for the analysis of residual geothermal gases: Chromatographia, v. 20, p. 681-682.

(P) Simpson, R. W., Jachens, R. C., Blakely, R. J., and Saltus, R. W., 1986, A new isostatic residual gravity map of the conterminous United states with a discussion on the significance of isostatic residual anomalies: Journal of Geophysical Research, v. 91, p. 8348-8372.

(A) Smith, C. L., Ficklin, W. L., and Thompson, J. M., 1984, Enrichment of arsenic, antimony, and tungsten in the waters of some modern high-temperature geothermal systems (abs.): Geological Society of America Abstracts with Programs, v. 16, no. 6, p. 660.

(P) Smith, R. L., and Luedke, R. G., 1984, Potentially active volcanic lineaments and loci in western conterminous United States, in Boyd, F. R., Jr., Panel Chairman, Explosive Volcanism: Inception, Evolution, and Hazards: Washington, D.C., National Academy Press, p. 47-66.

(P) Smith, R. B., Schilly, M. M., Braile, L. W., Ansorge, J., Lehman, J. L., Baker, M. R., Prodehl, C., Healy, J. H., Mueller, S., and Greensfelder, R. W., 1982, The 1978 Yellowstone-eastern Snake River Plain seismic profiling experiment: crustal structure of the Yellowstone region and experiment design: Journal of Geophysical Research, v. 87, p. 2583-2596.

(0) Sorey, M. L., 1984, Evolution and present state of the hydrothermal system in Long Valley caldera, in Hill D. P., Bailey, R. A., and Ryall, A. S., eds., Active tectonic and magmatic processes beneath Long Valley caldera, eastern California: U.S. Geological Survey Open-File Report 84-939, p. 617-658.

(P) Sorey, M. L., 1985, Evolution and present state of the hydrothermal system in Long Valley caldera: Journal of Geophysical Research, v. 90, p. $11,219-11,228$.

(A) Sorey, M. L., 1985, Types of hydrothermal convection systems in the Cascade Range of California and Oregon, in Guffanti, M., and Muffler, L. J. P, eds., 1985, Proceedings of the workshop on geothermal resources of the Cascade Range: U.S. Geological Survey Open-File Report 85-521, p. 63-67.

(P) Sorey, M. L., 1985, Present state of the hydrothermal system in Long Valley caldera, California: Geothermal Resources Council Transactions, v. 9, part I, p. 485-490.

(A) Sorey, M. L., 1985, Aquifers as low-temperature geothermal energy sources (abs.): Geological Society of America Abstracts with Programs, v. 17, no. 7, p. 722 .

(P) Sorey, M. L., and Ingebritsen, S. E., 1983, Evolution of 1iquid-dominated hydrothermal systems with parasitic vapor-dominated zones:

Proceedings of 5 th New Zealand Geothermal Workshop, 1983, p. 17-22.

(P) Sorey, M. L., and Ingebritsen, S. E., 1983, Numerical simulations of the hydrothermal system at Lassen Volcanic National Park: Proceedings of the 9 th Workshop on Geothermal Reservoir Engineering, Stanford University, p. 365-372. 
(0) Sorey, M. L., and Ingebritsen, S. E., 1984, Quantitative analysis of the hydrothermal system in Lassen Volcanic National Park and Lassen Known Geothermal Resource Area: U.S. Geological Survey, Water Resources Investigations Report 84-4278, $80 \mathrm{p}$.

(A) Sorey, H. L., and Ingebritsen, S. E., 1986, Evolution of the hydrothermal convection system at Lassen Volcanic National Park (abs.): Eos, Transactions American Geophysical Union, v. 67, p. 272.

(A) Sorey, H. L., Ingebritsen, S. E., and Mariner, R. H., 1986, Geothermal systems in the Cascade Range (abs.), in USGS Research on Energy Resources - 1986, Program and Abstracts: U.S. Geological Survey Circular 974, p. 64.

(P) Sorey, M. L., Nathenson, M., and Smith, C., 1983, Methods for assessing low-temperature geothermal resources, in Reed, M. J., ed., Assessment of low-temperature geothermal resources of the United States: U.S. Geological Survey Circular 892, p. 17-30.

(P) Sorey, M. L., Reed, M. J., Foley, D., and Renner, J. L., , 1983, Low-temperature geothermal resources in the central and eastern United States, in Reed, H. J., ed., Assessment of low-temperature geothermal resources of the United States: U.S. Geological Survey Circular 892, p. 51-65.

(P) Sorey, M. L., Reed, M. J., Mariner, R. H., and Nathenson, M., 1982, Assessment of low-temperature geothermal resources in the United States: Geothermal Resources Council Transactions, v. 6, p. 479-482.

(P) Sparlin, M. A., Braile, L. W., and Smith, R. B., 1982, Crustal structure of the eastern Snake River Plain determined from ray trace modeling of seismic refraction data: Journal of Geophysical Research, v. 87, p. 2619-2633.

(P) Stanley, W. D., 1982, Magnetotelluric soundings of the Idaho National Engineering Laboratory facility, Idaho: Journal of Geophysical Research, v. 87, p. 2683-2691.

(0) Stanley, W. D., 1982, A regional magnetotelluric survey of the Cascade Range region, northwestern United States: U.S. Geological Survey Open-File report $82-126,387 \mathrm{p}$.

(A) Stanley, W. D., 1983, Regional and local geoelectrical structures in the Cascades and their role in geothermal and volcano hazard assessment (abs.): Eos, Transactions American Geophysical Union, v. 64, p. 887 .

(P) Stanley, W. D., 1984, Tectonic study of Cascade Range and Columbia Plateau in Washington state based upon magnetotelluric soundings: Journal of Geophysical Research, v. 89, p. 4447-4460.

(P) Stauber, D. A., 1982, Two-dimensional compressional wave velocity structure under San Francisco volcanic field, Arizona, from teleseismic $P$ residual measurements: Journal of Geophysical Research, v. 87, p. 5451-5459.

(A) Stauber, D. A., and Iyer, H. M., 1983, Inversion for seismic velocity structure using teleseismic travel tims to arrays of station (abs.): IASPEI Symposium on Barthquake Algorithm, IUGG General Assembly, Hamburg, Germany.

(P) Stauber, D. A., Iyer, H. M., Mooney, W. D., and Dawson, P. B., 1985, Three-dimensional P-velocity structure of the sumit caldera of Newberry volcano, Oregon: Geothermal Resources Council Transactions, v. 9, part II, p. 411-415.

(A) Stauber, D. A., Riote, A., and Iyer, H. H., 1983, Evidence for subduction and magma genesis under the Oregon Cascades from teleseismic P-wave residuals (abs.): Inter-disciplinary symposium on structures and Processes in Subduction Zones: International Union of Geodesy and Geophysics, XVIII Federal Assembly, Hamburg, Germany. 
(A) Stockman, H. W., Westrich, H. R., and Miller, C. D., 1985, Geochemistry of Obsidian Dome and the Inyo dike: an overview (abs.): Bos, Transactions American Geophysical Union, v. 66, p. 385.

(A) Sturchio, M. C., Binz, C. M., Keith, T. E. C., and White, D. E., 1985, The longevity of thermal areas at Yellowstone: 238 U-series ages of hydrothermal precipitates from drill cores and sinters (abs.): Eos, Transactions American Geophysical Union, v. 66, p. 1082.

(P) Tamanyu, S., and Lanphere, M. A., 1983, Volcanic and geothermal history at the Hachimantai geothermal field in Japan--on the basis of $\mathrm{K}-\mathrm{Ar}$ ages: Journal of the Geological Society of Japan, v. 89, p. 501-510.

(P) Tanaka, K. L., Shoemaker, E. M., Ulrich, G. E., and Wolfe, E. W., 1986, Migration of volcanism in the San Francisco volcanic field, Arizona: Geological Society of America Bulletin, v. 97, p. 129-141.

(P) Thompson, J. M., 1982, Preliminary chemical studies of thermal waters in Lassen Volcanic National Park and vicinity: Geothermal Resources Council Transactions, v. 6, p. 115-118.

(0) Thompson, J. M., 1983, Chemical analyses of thermal and nonthermal springs in Lassen Volcanic National Park and vicinity, California: U.S. Geological Survey Open-File Report 83-311, 26 p.

(P) Thompson, J. M., 1984, The Konocti Bay fault zone, Lake County, California: a reevaluation: Geothermal Resources Council Transactions, v. 8, p. 383-389.

(P) Thompson, J. M., 1985, Chemistry of thermal and nonthermal springs in the vicinity of Lassen Volcanic Mational Park: Journal of Volcanology and Geothermal Energy, v. 25, p. 81-104.

(P) Thompson, J. M., Grunder, A. L., and Hildreth, W., 1983, Selected chemical analyses and geothermometry of hot-spring waters from the Calabazos Caldera, central Chile: Geothermal Resources Council Transactions, v. 7, p. 331-335.

(A) Thompson, J. M., Howe, S. S., and Hall, W. E., 1983, Chemical analysis of fluid inclusions by ion chromatography (abs.): Abstracts and Meeting Program 25th Rocky Mountain Conference, p. 108.

(A) Thompson, J. M., and Keith, T. E. C., 1983, Cesium in rock-water interaction, Yellowstone National Park (abs.): Geological Society of America Abstracts with Programs, v. 15, no. 5, p. 416-417.

(A) Thompson, J. M., and Keith, T. E. C., 1984, Chloride and fluoride in waters draining the Valley of 10,000 Smokes, Alaska (abs.): Geological Society of America Abstracts with Programs, v. 16, no. 5, p. 336-337.

(P) Thompson, J. M., Keith, T. E. C., and Consul, J. J., 1985, Water chemistry and mineralogy of Morgan and Growler hot springs, Lassen KGRA, California: Geothermal Resources Council Transactions, v. 9, part I, p. 357-362.

(A) Thompson, J. M., Mariner, R. H., and White, L. D., 1986, Chemistry of waters along the Konocti Bay fault zone (abs.): Eos, Transactions American Geophysical Union, v. 67, p. 1259.

(A) Thompson, J. M., White, L. D., Casadeval1, T. J., Maley, C. A., and Keith, T. E. C., 1985, Hot springs depositing travertine at Mount St. Helens (abs.): Eos, Transactions American Geophysical Union, v. 66, p. 1154.

(P) Thompson, R. A., and Dungan, M. A., 1984, Multiple fractionation processes in early-rift volcanics, northern Rio Grande rift, New Mexico, in Dungan, M. A., Grove, T. L., and Hildreth, Wes, eds., Proceedings of the Conference on Open Magmatic Systems, Ranchos de Taos, New Mexico: Southern Methodist University, p. 88-90. 
(P) Thompson, R. A., Dungan, M. A., and Lipman, P. W., 1986, Multiple differentiation processes in early-rift calc-alakaline volcanics, northern Rio Grande Rift, New Mexico: Journal of Geophysical Research, v. 91, p. 6046-6058.

(P) Trembour, F., and Friedman, I., 1984, The present status of obsidian hydration dating, in Mahaney, w., ed., Quaternary Dating Methods, Elsevier, New York, p. 141-153,

(0) Trimble, D. A., Clynne, M. A., and Robinson, S. W., 1984, The application of uranium-thorium systematics to rocks from the Lassen dome field, California: U.S. Geological Survey Open-File Report 84-371, 100 p.

(P) Truesde11, A. H., D'Amore, F., and vieva, David, 1984, The effects of localized aquifer boiling on fluid production at Cerro Prieto: Geothermal Resources Council Transactions, v. 8, p. 223-229.

(A) Truesdell, A. H., Duffield, W. A., and Abu Ajamieh, M., 1983, Origin and heat source of thermal waters at Zerqa Ma'in and Zara, Jordan (extended abs.): Extended Abstracts, 4th International Symposium on Water-Rock Interaction, Misasa, Japan, 1983, p. 508-511.

(A) Truesdell, A. H., Haizlip, J. R., Box, T. W., and D'Amore, F., 1986, The Geysers and Larderello, a geochemical comparison of steam systems (abs.): American Association of Petroleum Geologists Bulletin, $v$. 70, no. 7, p. 937.

(P) Truesdell, A. H., and Henley, R. W., 1982, Chemical equilibria in the Cerro Prieto hydrothermal fluid: Proceedings of 4th Symposium on the Cerro Prieto Geothermal Field, Baja California, Mexico, Guadalajara, Mexico, August 10-12, 1982, p. 515-520.

(A) Truesdell, A. H., and Janik, C. J., 1986, Reservoir fluids of the Baca, New Mexico, geothermal field (abs.), in USGS Research on Energy Resources - 1986, Program and Abstracts: U.S. Geological Survey Circular 974, p. 66-67.

(P) Truesdell, A. H., and Janik, C. J., 1986, Reservoir processes and fluid origins in the Baca geothermal system, Valles caldera, New Mexico: Journal of Geophysical Research, v. 91, p. 1817-1833.

(P) Truesdell, A. H., Janik, C. J., Goff, F., Grigsby, C. 0., Shevenell, L., and Paredes P. R., 1986, The geochemistry of the San Ignacio hot springs, Honduras: Geothermal Resources Council Transactions, v. 10, p. $155-160$.

(P) Truesdel1, A. H., Janik, C. J., and Samel, E. A., 1984, Geochemistry of thermal well waters at Klamath Falls, Oregon, Chapter 3, in Sammel, E. A., ed., Analysis and interpretation of data obtained in tests of the geothermal aquifer at Klamath Falls, Oregon: U.S. Geological Survey WaterResources Investigations 84-4216, p. 3-1 3-20.

(A) Truesdel1, A. H., Janik, C. J., and Stallard, M. L., 1985, Gas, isotope, and water chemistry indicate source and temperature of Honduran geothermal waters (abs.): Bos, Transactions American Geophysical Union, v. 66, p. 1155.

(P) Truesdel1, A. H., and Lippmann, H. J., 1986, The lack of immediate effects from the 1979-80 Imperial and victoria earthquakes on the exploited Cerro Prieto geothermal reservoir: Geothermal Resources Council Transactions, v. 10, p. 405-411.

(P) Truesdel1, A. H., Mazor, E., and Nehring, U. L., 1983, The origin of thermal fluids at Lassen National Park: evidence from noble and reactive gas abundances: Geothermal Resources Council Transactions, v. 7, p. 343-348.

(A) Truesdel1, A. H., Nehring, M. L., Des Marais, D. J., and Mazor, E., 1982, Geochemistry of gases in the hydrothermal system of Cerro Prieto, Mexico (abs.): Proceedings of Pacific Geothermal Conference 1982 incorporating the 4th New Zealand Geothermal Workshop, p. 271. 
(P) Truesdel1, A. H., Nehring, N. L., Thompson, J. H. , Janik, C. J., and Coplen, T. B., 1984, A review of progress in understanding the fluid geochemistry of the Cerro Prieto geothermal system: Geothermics, v. 13, p. $65-74$.

(P) Truesde11, A. H., and Thompson, J. H., 1982, The geochemistry of Shoshone Geyser Basin, Yellowstone National Park: Wyoming Geological Association Guidebook 33rd Annual Field Conference, p. 153-159.

(P) Urban, T. C., and Diment, W. H., 1982, An interpretation of precision temperature logs in a deep geothermal well near Desert Peak, Churchill County, Nevada: Geothermal Resources Council Transactions, v. 6, p. 317-320.

(P) Urban, T. C., and Diment, W. H., 1985, Convection in borehole; limits on interpretation of temperature logs and methods for determining anomalous fluid flow: in surface and borehole geophysical methods in ground water investigations, National Water Well Association, p. 399-414.

(0) Urban, T. C., Diment, W. H., Nathenson, M., Smith, E. P., Ziagos, J. P., and Shaeffer, M. H., 1986, Temperature, thermal-conductivity, and heat-flux data: Raft River area, Cassia County, Idaho (1974-1976): U.S. Geological Survey Open-File Report 86-123, 299 p.

(P) Wallace, R. H., Jr., 1985, Geothermal plants increased in 1984: Geotimes, v. 30 , no. 8, p. $20-21$.

(A) Wallace, R. H., Jr., 1986, Geopressured-geothermal energy potential - 1986 (abs.), in USGS Research on Energy Resources - 1986, Program and Abstracts: U.S. Geological Survey Circular 974, p. 69-70.

(P) Walter, S. R., Rojas, Veronica, and Kollman, Auriel, 1984, Seismicity of the Lassen Peak area, California, 1981-1983: Geothermal Resources Council Transactions, v. 8, p. 523-527.

(0) Wang, J., and Munroe, R. J., 1982, Heat flow and sub-surface temperatures in the Great Valley, California: U.S. Geological Survey Open-File Report 82-844, 102p.

(A) Ward, P. L., 1985, Silicic magma bodies extend all the way through the lithosphere (abs.): Eos, Transactions American Geophysical Union, v. 66, p. 397 .

(A) Weaver, C. S., 1983, Seismicity and seismotectonic boundaries in Washington (abs.): Earthquake Notes, v. 54, no. 1, p. 40.

(A) Weaver, C. S., 1985, Combined regional seismotectonics and the extent of Cenozoic volcanism: an improved first-order geothermal assessment of the Cascade Range? in Guffanti, M., and Muffler, L. J. P, eds., 1985, Proceedings of the workshop on geothermal resources of the Cascade Range: U.S. Geological Survey Open-File Report 85-521, p. 14-17.

(P) Weaver, C. S., Green, S. M., and Iyer, H. M., 1982, Seismicity of Mt. Hood and structure as determined from teleseismic $P$-wave delay studies: Journal of Geophysical Research, v. 87, p. 2782-2792.

(A) Weaver, C. S., and Michaelson, C. A., 1983, Segmentation of the Juan de Fuca plate and volcanism in the Cascade Range (abs.): Eos, Transactions American Geophysical Union, v. 64, p. 886.

(P) Weaver, C. S., and Michaelson, C. A., 1985, Seismicity and volcanism in the Pacific Northwest: evidence for segmentation of the Juan de Fuca plate: Geophysical Research Letters, v. 12, p. 215-218.

(A) Weaver, C. S., and Zollweg, J. E., 1982, Deep earthquakes and possible magmatic gas transport at Mount st. Helens, Washington (abs.): Eos, Transactions American Geophysical Union, v. 63, p. 1140 .

(P) Weaver, C. S., Zollweg, J. E., and Malone, S. D., 1983, Deep earthquakes beneath Mount st. Helens: Evidence for magmatic gas transport?: Science, v. 221 , no. 4618 , p. 1391-1394. 
(P) Welch, A. H., and Olmsted, F. H., 1984, Geothermal systems of western Nevada, in Lintz, Joseph, Jr., ed., Western geological excursions: Geological Society of America Annual Meetings, Reno, Nevada, v. 3, p. 145-146.

(P) Welch, A. H., and Preissler, A. M., 1986, Aqueous geochemistry of the Bradys Hot Springs geothermal area, Churchill County, Nevada, in Subitsky, S., ed., Selected papers in the hydrologic sciences: U.S. Geological Survey Water-Supply Paper 2290, p. 17-36.

(A) Wernicke, B. P., Christiansen, R. L., England, P. C., and Sonder, L. J., 1985. Tectonomagmatic evolution of Cenozoic extension in the North American Cordillera (abs.): Abstract 28 in Continental Extensional Tectonics, University of Durham, England, April 1985.

(P) White, A. F., Delaney, J. H., Truesdel1, A. H., Janik, C. J., Goff, F., and Crecraft, H., 1984, Fluid chemistry of the Baca geothermal field, Valles caldera, New Mexico: New Mexico Geological Society Guidebook of the 35th Annual Field Conference, p. 257-263.

(P) White, D. E., 1985, Vein and disseminated gold-silver deposits of the Great Basin through space and time, in Tooker, B. W., ed., Geologic Characteristics of Sediment- and Volcanic-Hosted Disseminated Gold Deposits - Search for an Occurrence Model: U.S. Geological Survey Bulletin 1646, p. 5-14.

(A) White, D. B., 1986, U.S. Geological Survey investigations of active geothermal systems, 1945-present (abs.): Bos, Transactions American Geophysical Union, v. 67, p. 281.

(A) White, D. B., 1986, Subsurface waters of different origins (extended abs.): Fifth International Symposium on Water-Rock Interaction Extended Abstracts, Reykjavik, Iceland, August, 1986, p. 629-632.

(P) White, D. B., and Heropoulos, C., 1983, Active and fossil hydrothermalconvection systems of the Great Basin, in The role of heat in the development of energy and mineral resources in the northern Basin and Range province: Geothermal Resources Council, Special Report no. 13, p. 41-53.

(A) White, L. D., Thompson, J. H., and Maley, C. A., 1985, Evidence for thermal water in Crater Lake, Oregon (abs.): Eos, Transactions American Geophysical Union, v. 66, p. 1146.

(P) Williams, D. L., 1982, Review of the book "Geysers and Geothermal Energy" by J. S. Rinehart: Eos, Transactions American Geophysical Union, v. 63, P. $187 \ldots$

(A) Williams, D. L., and Finn, C., 1983, Gravity studies in volcanic terranes (abs.): Geophysics, v. 48, p. 454 (Extended version printed in the Technical Program of the 52nd Annual International Meeting of the Society of Exploration Geophysicists, 1982, Dallas, TX, p. 303-305).

(P) Williams, D. L., and Finn, C., 1985, Analysis of gravity data in volcanic terrain and gravity anomalies and subvolcanic intrusions in the Cascade Range, U.S.A., and at other selected volcanoes: in Hinze, $W$. J., ed., The utility of regional gravity and magnetic anomaly maps, Society of Exploration Geophysicists, p. 361-374.

(P) Williams, D. L., Finn, C., Spydel1, D. R., and Danes, F., 1984 , Gravity and aeromagnetic maps of the Goat Rocks Wilderness and adjacent Roadless areas, Lewis and Yakima counties, Washington: U.S. Geological Survey Miscellaneous Field Studies Map, MF-1653-C, scale $1: 48,000$.

(P) Williams, D. L, Hul1, D. A., Ackermann, H. D., and Beeson, H. 'H., 1982, The Mt. Hood region: volcanic history, structure, and geothermal energy: Journal of Geophysical Research, v. 87, p. 2767-2781. 
(P) Williams, D. L., and Keith, T. E. C., 1982, Aeromagnetic and Bouguer gravity maps of Mount Hood Wilderness, Clackamas and Hood River counties, Oregon: U.S. Geological Survey Miscellaneous Field studies Map IF 1379-D, scale 1:62,500.

(P) Williams, D. L., and Von Herzen, R. P., 1983, On the terrestrial heat flow and physical limnology of Crater Lake, Oregon: Journal of Geophysical Research, v. 88, p. 1094-1104.

(A) Winnett, T., and Janik, C., 1986, Isotopic composition of carbon in fluids from the Long Valley geothermal system, California, U.S.A. (abs.): Fifth International Symposium on Water-Rock Interaction Extended Abstracts, Reykjavik, Iceland, August, 1986, p. 637-640.

(P) Wolfe, E. W., Ulrich, G. E., and Moore, R. B., 1983, San Francisco volcanic field, Arizona: Volcano News, no. 13, p. 1-3.

(A) Wollenberg, H. A., White, A., Flexser, S., Sorey, M., Farrar, C., and Bartel, L., 1986, A core hole in the southwestern moat of the Long Valley caldera: early returns (abs.): Bos, Transactions American Geophysical Union, v. 67, p. 1258.

(P) Wollenberg, H. A., White, A., Sorey, M., Farrar, C., and Bartel, L., 1986, Research core hole completed at Long Valley: Eos, Transactions American Geophysical Union, v. 67, p. 582.

(P) Young, H. W., 1985, Geochemistry and hydrology of thermal springs in the Idaho Batholith and adjacent areas, central Idaho: U.S. Geological Survey Water Resources Investigations WRI 85-4172, 44 p.

(P) Young, H. W., and Lewis, R. E., 1982, Hydrology and geochemistry of thermal ground water in southwestern Idaho and north-central Nevada: U.S. Geological Survey Professional Paper 1044-J, 20p.

(A) Younker, L. W., Eichelberger, J. C., Lysne, P. C., and Miller, C. D., 1985, Scientific drilling at Inyo Domes, California - Summary and the future (abs.): Eos, Transactions American Geophysical Union, v. 66, p. 388.

(A) Zohdy, A. A. R., 1985, Characterization of geothermal systems in the Cascade Range from geoelectrical studies, in Guffanti, M., and Muffler, L. J. P, eds., 1985, Proceedings of the workshop on geothermal resources of the Cascade Range: U.S. Geological Survey Open-File Report 85-521, p. 73-74.

(0) Zohdy, A. A. R., and Bisdorf, R. J., 1982, Schlumberger soundings in the Medicine Lake area, California: U.S. Geological Survey Open-File Report 82-887, $162 \mathrm{p}$.

(P) Zucca, J. J., Fuis, G. S., Milkereit, B., Mooney, W. D., and Catchings, R. D., 1986, Crustal structure of northeastern California: Journal of Geophysical Research, v. 91, p. 7359-7382. 